Portland State University

PDXScholar

$12-1-1971$

\title{
The Lair Hill Park neighborhood on examination of the phenomenon of community creation
}

Joseph S. Uris

Portland State University

Follow this and additional works at: https://pdxscholar.library.pdx.edu/open_access_etds Let us know how access to this document benefits you.

\section{Recommended Citation}

Uris, Joseph S., "The Lair Hill Park neighborhood on examination of the phenomenon of community creation" (1971). Dissertations and Theses. Paper 727.

https://doi.org/10.15760/etd.727

This Thesis is brought to you for free and open access. It has been accepted for inclusion in Dissertations and Theses by an authorized administrator of PDXScholar. Please contact us if we can make this document more accessible: pdxscholar@pdx.edu. 
AN ABSTRACT OF THE THESIS OF Joseph S. UrIs for the

Master of Arts In Soclology presented December 15, 1970.

Title: The Lair Hill Park Nelghborhood on Examination of the Phenomenon of Community Creation.

APPROVED BY MEMBERS OF THE THESIS COMMITTEE:

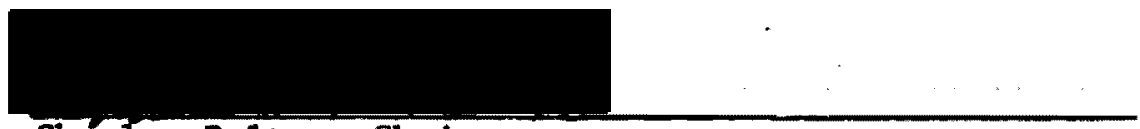

Chárles Bolton, Chal rman

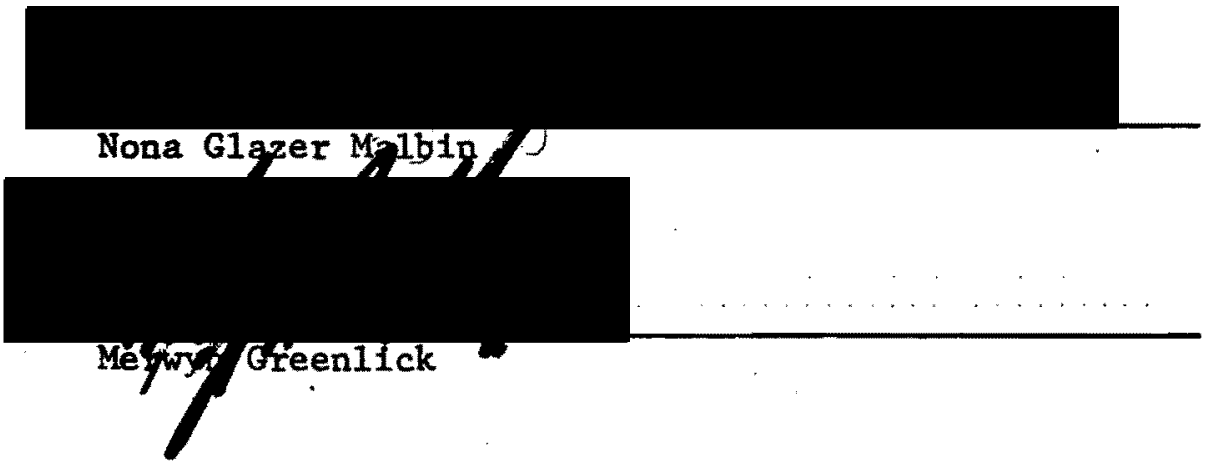

This thesis is a study of a communtty in physical 1solation. The first chapter describes the methodology used. Short form questionnalres and in-depth interviews were gathered. Three sets of historical maps were'drawn from documented sources. A film describing the life style and bellefs of some community residents was made. The second chapter is an evaluation of some of the 11terature on the ne1ghborhood. This chapter detalls the hypothesis that external pressures and externally created needs tended In the case of the Lalr HIII area to produce a Gemelnschaft-1ike situation which proves stronger than the many factors making for heterogeneity in this ethnically and culturally and generattonally mixed community. Chapter three detalls the history of the neighborhood: first, from the turn of the century to the beginning 
of urban renewal in 1958; second, from 1958 to the present day. Chapter four detalls both the heterogeneous and homogeneous factors in interaction in the community and further explores the conflict between exterfor soclety and the common interest of the people in the Lair H1ll community. 
THE LAIR HILI PARK NEIGHBORHOOD ON EXAMINATION

OF THE PHENOMENON OF COMMUNITY CREATION

by

JOSEPH S. URIS

A thesis submitted in partial fulfillment of the

requirements for the degree of

MASTER OF ARTS

in

SOCIOLOGY

$+2$

Portland State University

1971 


$$
4
$$

$$
\begin{aligned}
& \text { Copyright } 1970 \text { by Joseph S. Unis. } \\
& \text { Nopht of. This woak may be nepnoduced } \\
& \text { without wnitten consent of The authon. }
\end{aligned}
$$


TO THE OFFICE OF GRADUATE STUDIES:

The members of the Committee approve the thesis of

Joseph S. Uris presented December 15, 1970.
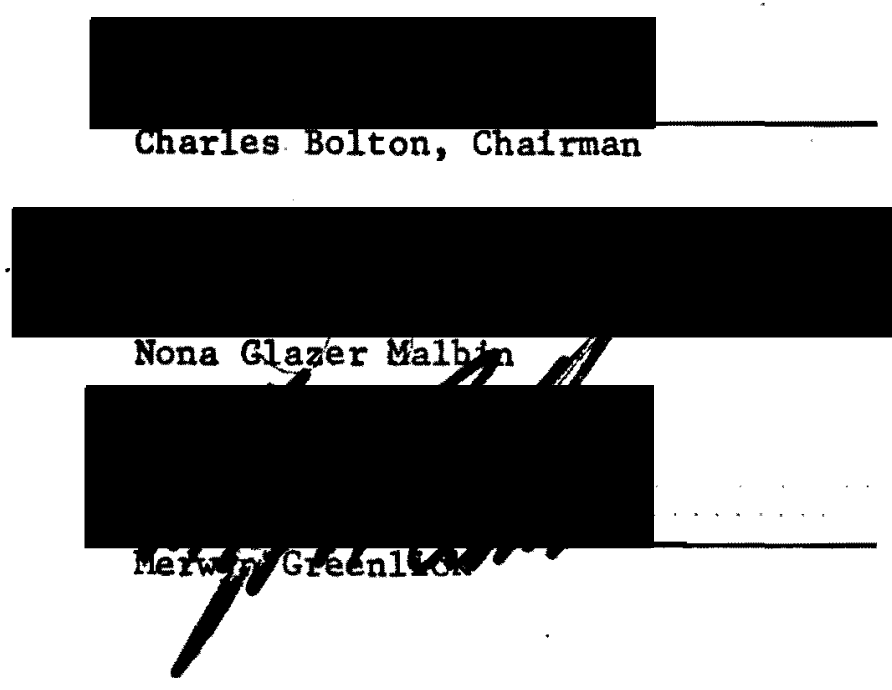

APPROVED:

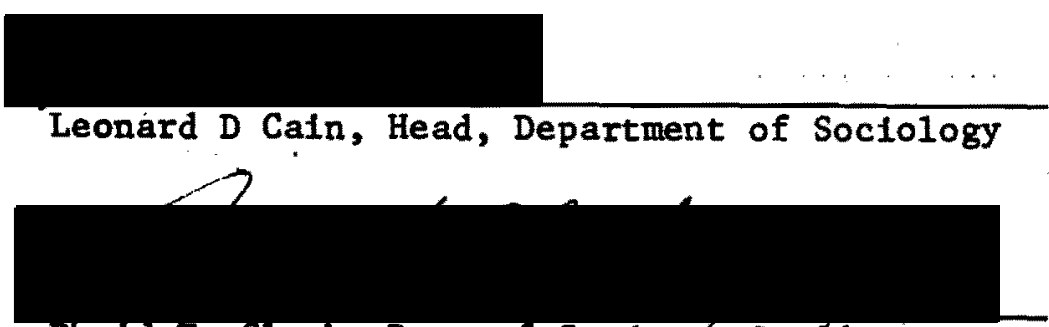

David T. Clark, Dean of Graduate Stuides

December 15, 1970 


\section{PREFACE AND ACKNOWLEDGMENTS}

It could be said that this thesis began when I moved to Laix Hill in October, 1964. I moved to the area for the relatively "Bohemian". community and low rent housing. Soon I came to regard it highly for other traits, namely, its racially and ethnically integrated population--a body of comradely though seemingly heterogeneous people. It was in the process of taping interviews that I later learned how highly valued these things are for many who still live in the community. My wife and I lived in the area for three years; we left but returned in May 1968 to stay another six months. During this latter stay, I operated the Merchants of Warm, a "hip"-oriented self-help agency. It was during this period that Lair Hill became the center for a large, noisy street population and subsequent housing inspections and demolition. My interest then turned into developing a study of a particular population as a threatened community.

Thanks and credit in assembling this thesis go to carol Rubenstein for her assistance in in-depth interviewing, Denise Jacobson for her film editing and advice, Bev Walton for her copy editing and research, Janet Christ for her typing and advice, and cameramen Bob Summers and Hal Lesser. Thanks should also go to the Oregon Historical Society, whose able staff and records made much that was unknown, known. 
I am indebted to Charles Bolton, Merwyn Greenlick and Nona Glazer Malbin, members of my thesis advisory committee, for their encouragement, criticism and amused insistence. Particular thanks go to the Lair Hill residents whose trust and cooperation made this thesis possible. It is unfortunate that I shall benefit from what will help them so little. 
TABLE OF CONTENTS

PAGE

PREFACE AND ACKNOWLEDGMENTS

iii

LIST OF TABLES . . . . . . . . . . . . . •

vii

CHAPTER

I INTRODUCTION . . . . . . . . . . •

1

II METHODOLOGY . . . . . . . . . . .

4

In-Depth Interviews . . . . . . .

4

Short Questionnaire Interviews . . .

6

Respondents' Attitude . . . . . .

7

Documentation: Preparing the Maps . .

8

Portrayal: Preparing the Film . . .

9

III THEORY . . . . . . . . . . . . .

12

Neighboring . . . . • . . . • •

12

Ethnicity, Mobility and Neighborhood •

13

Blacks, Integration and Segregation . •

16

Ethnic Elite--The Jews . . . . .

19

A Typology of Residents . . . . .

Gemeinschaft-Gesellschaft . . . •

21

Community as Territory . . . . . •

22:

The Generation of Community

Consciousness . . . . . . . . 
Furthering the Generation of Gemeinschaft: Social Interaction ....

Conflict and Contradiction: Community Through Accommodation .......

Geographic Sources - 1900-1955

Informant Information . . . . . .

Religious Life . . . . . . . .

The Eastern Jewish Influx . . . . .

Physical Isolation of the Neighborhood.

Historical Heterogeneity . . . . .

Generational Factors ........ 45

Urban Renewal ........... . . 46

v THE NEIGHBORHOOD . . . . . . . . .

From the Interviews . . . . . . . 52

Ethnocultural Groupings and Typology . 55

The End of one Ethnic Iine, Another Continues ...........

Conditions . . . . . . . . .

Continuity and Tradition . . . . .

Strains on Neighboring . . . . . .

Life-style and work . . . . . . .

Fun, Music and Trouble--Integrating

Forces $\ldots \ldots$

Outsiders and Insiders . . . . . . 75

Social Control and Power Efforts . . . 77

Facing Urban Renewal . . . . . . 78 
CHAPTER

vii

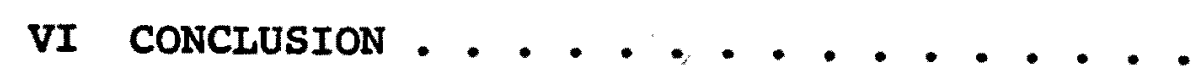

PAGE

FOOTNOTES . . . . . . . . . . . . . . . . . .

81

A LIST OF WORKS CONSULTED . . . . . . . . . . . . .

85

APPENDIX

88

91

$\checkmark$

$\div$ 


\section{IIST OF TABLES}

TABIE

PAGE

I In-Depth Interview Schedule . . . . . . 10

II Short questionnaire Interview Schedule . . . 11

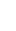




\section{CHAPTER I}

\section{INTRODUCTION}

Lair Hill is a wedge of city land with some 200 households, a community which, as part of Portland's old Southwest area, has been subjected to a series of transformations. The area has been bisected by a street extension, then by a freeway, and further altered by urban renewal. In this isolating process, the district has lost the majority of its predominantly Italian and Jewish population, has lost many commercial establishments, and has assumed an influx of black and young white people. Now, a half mile of run-down community, Lair Hill yet continues in the traditions of neighborhood life.

This paper is an analysis of Lair Hill as an isolated community, how it has come to be, the interactions which occur within its boundaries, and the forces which cause these interactions. The hypothesis of this paper is that a Gemeinschaft-like situation has developed in Lair Hill because area residents perceive forces outside the Lair Hill area as endangering the maintenance of location, housing and life- $\psi^{*}$ style.

The thesis's second chapter (Methodology) discusses the basic techniques utilized in gathering material for this 
paper. Participant observation is a primary source of neighborhood information. As well, 67 interviews, including 114 residents, have been conducted in Lair Hill. A film of the community has been created. Historical maps have been made to illustrate property developments and documented changes in Portland's Southwest area.

The third chapter of this paper is theoretical. It draws from the writings of suttles, Redfield, Tơnnies, Homans, Simmel, Marcuse, Mao and others. The chapter (1) examines factors of heterogeneity in the neighborhood; (2) details a typology of residents which will be used throughout this work; (3) discusses the causes for homogeneity within the area--these causes are introduced in terms of notions derived from the appropriate role of conflict in the creation of what the author believes to be an exteriorly-created Gemeinschaft-like neighborhood.

The fourth chapter is a history of the neighborhood. Community events and conditions are outlined beginning near the turn of the century, when "greenhorns" from Europe massed in the area, following through to Lair Hill's "hippie invasion" in 1968. Several events are identified as factors leading not only to the isolation of the neighborhood but to the creation of its Gemeinschaft-like qualities.

The fifth chapter is a more intimate chronicle of the interactions of Lair Hill residents: Generational factors and cultural affinities between multi-generational black 
3

people and the newer young white people in the area are explored. In addition, the relative aloofness and nostalgic attitude of older Jewish and Italian residents are examined in terms of their cultural separateness and loss of "future"-not having young people of "their own" in Lair Hill. Homans's suggestion that frequent interaction leads to affecttion is studied in the order of its occurrence in the commanity, that is, new young residents first become friendly with blacks, then with Jewish and Italian residents. 
CHAPTER II

METHODOLOGY

"It ain't as homey as it used to be."

- Why is that?

"Cause there ain't so many homes."

- from a tape recorded

interview in Lair Hill

William Whyte in Street Corner Society ${ }^{l}$ chronicles the social order of slumgang and post-gang youths as well as that of older generation Italian immigrants. The appendix to his book provided the basic information from which much of the participant observation techniques used in this paper were derived.

\section{IN-DEPTH INTERVIEWS}

Taped in-depth interviews and short questionnaire interviews were conducted with area residents in the spring and summer of 1970. Since a fuller history of the neighborhood. could be expected from long-term residents, these people were called on most frequently for taped in-depth interviews. The relative high number of older, long term residents to other groups consulted is not, therefore, necessarily indicative of any majority group in the area. The in-depth interyiew population: 
those who have been residents for more than 25 years-16 those who have been residents for more than 10 years -13 those who have been residents for more than 5 years- 6 those who have been residents for more than 3 years- 3 those who have been residents for more than 1 year -3 those who have been residents for less than 1 year - 3

Interviews generally began with an introduction of the interviewer, some reminiscence of where and when he lived in the neighborhood, and a request for the interview itself. The author used basic information gained during his years in the community as well as his continued contact with area householders to affect an informal interview situation, to make the recorder seem less the intruder it might be. However, if the interview was held outdoors or the subject objected to being tape-recorded, the machine was unplugged, and when the interview was completed a transcription was taken from memory. This latter technique was only necessary in four out of a total of $\mathbf{4 4}$ interviews.

Because the interviewer had nearly five-years' knowledge of the neighborhood, he could suggest specific topics, events or locales to the interviewee. While this meant that the subject was, to a degree, led, it also meant that a more complete and concise picture of the vicinity was obtained during reminiscence. One subject's daughter who was raised in Lair Hill, and who is a University of Chicago graduate now living in Portland, served as interviewer for five taped accounts. Here again, the interyiewer's familiarity with the interviewee, and vice versa, and neighborhood made possible 
informal, personal interyiews. Where interviews are mentioned in this thesis, all names are fictitious.

The interviews were discontinued when: (1) representation of residents in all of the categories listed above were reached; (2) when there was a fair geographical distribution of interviews; (3) when subjects in each group began to repeat material preyiously given by other subjects. Glasser and Strauss, in The Discovery of Grounded Theory, ${ }^{2}$

call this manner of repetition "theoretical saturation". The authors suggest that repetition of information can be used as an indicator that available information has probably been exhausted and that no new information is likely to appear. For example, when subjects begin to repeat locations of various past businesses and events without contradiction, it can be assumed that the information gained is valid. (Pg. Iff) since these folk histories, with the exception of exact dates for certain events, conform to official records and gathered data, category exhaustion seemed a valid device for terminating the in-depth interviews.

\section{SHORT QUESTIONNAIRE INTERYIEWS}

A set of short interyiews were conducted for a more representative sampling of some 200 households in the Lair Hill area. These interyiews were not taped; rather subjects answered questions read to them and their replies were noted on a questionnaire form. Data were gathered on age, sex, 
employment, ethnic background, length of time in the neighborhood, length of time at present address, and neighborhood contacts. A total of 25 household interviews including 71 residents were completed. The short interview population:

those who have been residents for more than 25 years-14 those who have been residents for more than 10 years-15 those who have been residents for more than 5 years- 7 those who have been residents for more than 3 years- 7 those who have been residents for more than 1 year -10 those who have been residents for less than 1 year -18

Subjects for the short interviews were picked randomly in the neighborhood--one or two households to a block. No system was employed to choose households in the blocks.

\section{RESPONDENTS' ATTITUDES}

Unlike the two in-depth interviewers, the household survey interviewer had never lived in the area. When the interviewer initially identified herself as a representative of a local research foundation, subjects often announced their suspicion that information given would be used for "other" purposes; one admittedly gave false information and, in four cases, an interview was refused. However, when the interviewer identified herself as a Portland State University student working with the two other interviewers, subjects were more obliging.

Most subjects interviewed in-depth expressed a deep dislike for the U.S. Census and other official informationgathering agencies. These subjects said that they had, at 
times, lied or deliberately misled census workers. The common reason given for this behavior was that subjects resented and distrusted the intent of such agencies. Further, residents expressed a fear that data on the neighborhood would be used to justify urban renewal in the area. They sited the Office of Housing and Urban Development's (HUD) upcoming survey of Lair Hill as a likely case in point.

\section{DOCUMENTATION: PREPARING THE MAPS}

An official history of the neighborhood used for the three maps of the greater South Portland area--showing street and highway alterations, rededication of buildings and properties and dates of various structures--was supplied by the City Hall, the Multnomah County Auditor's Office and the Portland Development Commission. The oregon Historical Society was the source for old city directories, newspaper articles, letters, photographs and various other documents from which information was extracted for illustration. The Society's Sanborn Insurance Maps provided the most accurate official description of South Portland's natural and man-made features. Insurance maps referred to during the construction of the author's maps:

Portland corrected to 1909, vol. I; Portland corrected to 1926, vol. II; Portland corrected to 1955, vol. I; Portland corrected to the present by the author.

These maps show major street changes and the location 
of churches, synagogues, commercial establishments and private homes. Older maps show the gullies, bridges and railway trestles which have, for the most part, been eliminated.

\section{PORTRAYAI: PREPARING THE FIIM}

Since a major purpose of urban sociology should be the transmission of a real and comprehensible image of existing conditions, in the sense of how life is in the community, a motion picture of the Lair Hill area and its people has also been made. The film is designed as more than a simple visual aid. It is an effort to capture elements of neighborhood life in a particular environment. Scenes shot for the film include community gatherings, ranging from early morning prayer at the synagogue to an electrical music concert at the park.

The film, running approximately 12 minutes, is a $16 \mathrm{~mm}$ production with an overdubbed soundtrack. Manual cameras were used. Lighting was natural or limited to one 200 watt tungsten filament light bulb. In all cases, permission was gained from subjects before they were filmed. Two householids allowed cameramen access for interior shots. The soundtrack is composed of excerpts from in-depth interviews and from songs written by Lair Hill residents, Gregg Stoker and Jery Harley. 


\section{TABLE I}

IN-DEPTH INTERVIEW SCHEDULE

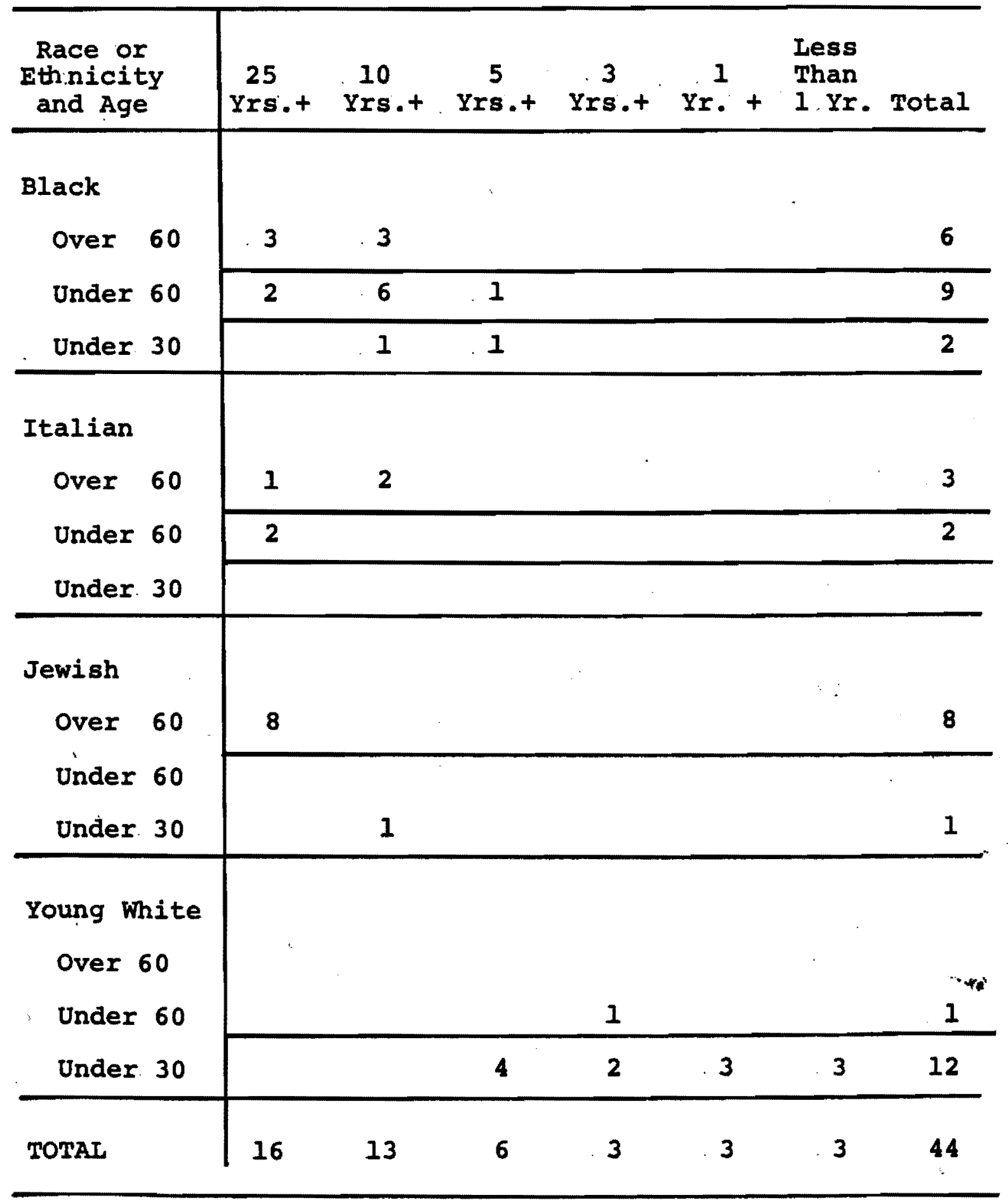


TABLE II

SHORT QUESTIONNAIRE INTERVIEW SCHEDULE

\begin{tabular}{|c|c|c|c|c|c|c|c|}
\hline $\begin{array}{l}\text { Race or } \\
\text { Ethnicity } \\
\text { and Age. }\end{array}$ & $\begin{array}{c}25 \\
\text { Yrs.t. }\end{array}$ & $\frac{10}{\text { Yrs.t }}$ & $\begin{array}{c}5 \\
\text { Yrs.t }\end{array}$ & $\frac{3}{\text { Yrs.t }}$ & $\stackrel{1}{y^{2}}+$ & $\begin{array}{l}\text { Less } \\
\text { Than } \\
1 \text { Yr. }\end{array}$ & Total \\
\hline \multicolumn{8}{|l|}{ Black } \\
\hline Over 60 & & 1 & & 1 & & & 2 \\
\hline Under 60 & & 5 & & 3 & & & 8 \\
\hline Under 30 & & 1 & & 1 & & & 2 \\
\hline \multicolumn{8}{|l|}{ Italian } \\
\hline Over 60 & 3 & & & & & & 3 \\
\hline Under 60 & 1 & & & & & & 1 \\
\hline \multicolumn{8}{|l|}{ Jewish } \\
\hline Over 60 & 4 & 2 & & & & & 6 \\
\hline Under 60 & 1 & 2 & & 1 & & & 4 \\
\hline \multicolumn{8}{|l|}{ Young White } \\
\hline Under 60 & & & 1 & & 1 & 4 & 6 \\
\hline Under 30 & & & & 1 & 9 & 14 & 24 \\
\hline \multicolumn{8}{|l|}{ Others } \\
\hline Over 60 & 4 & 2 & & & & & $6 *$ \\
\hline Under 60 & 1 & 1 & 3 & & & & 5. \\
\hline Under 30 & & 1 & 3 & & & & 4 \\
\hline TOTAI & 14 & 15 & 7 & 7 & 10 & 18 & 71 \\
\hline
\end{tabular}




\title{
CHAPTER III
}

\section{THEORY}

\begin{abstract}
"Portland Center was, in 1959, 54 blocks on the fringe of Portland's core area. The neighborhood was badly deteriorated. Taxwise, it was a liability."

--from a Portland Development Commission pamphlet entitled, "A glance at the work of the Portland Development Commission."

\section{NEIGHBORING}

Suzanne Keller in The Urban Neighborhood discusses "the neighbor" and "neighboring" as a special role and relationship. ${ }^{3}$ Neighboring involves cooperative activity in time of need. A typical example from our study includes going to the store for one's own provisions and getting supplies for a neighbor too. Keller points out that one needn't even know a neighbor's full name or conceive of one's action as part of a friendship for neighboring to exist among residents.

Keller notes the following generalizations about neighboring as an aspect of neighborhood living. In neighboring, the kind of relationship may vary, but exchange of services, information, and forms of support among those living near one another are basic to the relationship. The kinds of needs that cause these exchanges may range from collective needs that are seasonal or cyclical, such as harvesting and 
economic depression, to minor assistance or major emergencies. The kinds of aid rendered may be no more than verbal support or may extend, as it sometimes does in Lair Hill, to shared garden use and wood gathering. (p. 29ff) In most cases, neighboring behavior meets certain needs neglected or inadequately dealt with by formal social institutions.4

Reciprocal social control is another aspect of neighboring behavior. This aspect, as we shall see, varies in terms of homogeneity and shared cultural values within the community.

According to Keller, such things as distance of employment, transport, mass media, economic prosperity, and multiplicity of interests in the areas of work and play, tend to decrease neighboring behavior. (p. 44)

\section{ETHNICITY, MOBILITY AND NEIGHBORHOOD}

William F. Whyte in street Corner Society examines an Eastern American neighborhood in 1939. His work is a classic study on neighborhood. It is in this work that changing perceptions on the part of those escaping the working-class neighborhood are analyzed in terms of the effect that success and the successful will have on others of the neighborhood and on those who have escaped the area. "Corner boys," groups of low-status men who find social identity through particular street activities i.e., tavern hopping and 
poolroom gambling, who do not rise are seen by risers as 1azy. Those who do rise are pointed to by the upper-classes as examples of how democracy does indeed work.

Upward social mobility is often the prime goal of those coming to America, "the land of opportunity," and it is reasonable to suggest, the normative expectation for the great majority of American People. But access to success can be blocked. Lack of education, capital, contacts in the upper-class structure, and ethnic or racial differences--all of these are problems which are very real to the poor seeking success.

One agency which Whyte states quite obviously served to aid people in such things as Americanization, which in turn would make feasible their upward social mobility, is the settlement house.

The primary function of the settlement house is to stimulate social mobility, to hold out middle-class rewards to lower-class people. 'Since upward mobility almost always involves movement out of the slum district, the settlement is constantly with people who are on their way out of cornerville. It does not win the loyalty of the great majority of the people who look upon the district as their permanent home. (p 104)

Settlement houses are not generated by the people who are alleged to need them. As is the case with the Neighborhood House in Portland's Lair Hill area, it is the product of the more successful members of the same ethnic community who choose to help their less fortunate brothers. Whyte states that the greatest upward strides are made 
by the most aggressive of the newcomers. (p. 105) Aggressiveness and a willingness to drop or at least modify traditional values are important aspects of upward mobility. (p. 273) In our examination of Lair Hill, it will become apparent that it is the traditional, the orthodox, the unsuccessful and those whose access to the system seems permanently blocked who remain in Lair Hill.

The problems and conflicts of Cornerville are outlined by Whyte in his conclusion. He notes that there is social organization in the neighborhood, but it is in conflict with the greater society. Old world social customs and values conflict with the established economic order and access routes to success in that economic order.

Whyte sees those who remain in Cornerville as victims of an ethnic barrier. Social mobility is blocked for Italians. Success is limited to a small number from Cornerville. To get ahead, Cornerville men and women must choose between the world of business and its conservative Republican outlook, or Democratic machine politics and illegal activity. Cornerville is in an area where ward-type politics exist. The city of our study does not have this form of politics. City officials are elected at large. Neighborhood political power is non-existent. Access to the greater society may well depend upon financial success, which often means a college education, a professional career, an end to traditional ethnic values, and relocation outside the 
working-class community. As we shall see, hard work and self-denial have made it possible for the children of Lair Hill's white ethnic minorities (Italians and Jews) to leave the neighborhood, as they have done, and live in a "better" area.

In closing Whyte states: "In effect, the society at large puts a premium on disloyalty to Cornerville and penalizes those who are best adjusted to the life of the district." (p.274) our study will show that where the loyal remain, society can and does move to break up the poor community.

\section{BLACKS, INTEGRATION AND SEPARATION}

Robin M. Williams in Strangers Next Door, Ethnic Relations in American Communities details the problem of the integrated neighborhood. He indicates that prejudice is common in the neighborhood of his study. Prejudice is not necessarily rational or clearly formulated. It is most often expressed in the in-group situation away from the minority involved. Prejudicial attitudes without concomitance are disengaged. (p. 77)

williams found that negative reaction to black people in a white neighborhood is strongest among those who have the most to lose economically. These are homeowners 5 who fear loss in property value, members of the middle-class who fear loss of social status, and old timers who see in 
the appearance of black people the beginning of neighborhood deterioration. (p. 190) He also notes that the black response to white prejudice is the development of their own social life and formal social organizations. Portland's Black Elks is an example of this.

Apparently, despite white fears and prejudices, friendships between white and blacks do develop and flourish in integrated neighborhoods. Williams finds that those with approximately equal status in categories except ethnicity are most likely to establish friendships with black community members. Acceptance of derogatory stereotypes and negative sentiments toward blacks may, thus, be said to be limited by shared economic, educational, or occupational status.

Where there is an economic distance, either perceived or real, the more significant forms of social interaction will be limited. For Jews and Italians whose upward social mobility potential is less limited than blacks, social distance factors will become important. Thus, in our Lair Hill study we found that the Jew who owns three or four pieces of real estate in the neighborhood, who is both a landlord and a district dweller, wili tend to keep social distance from the black renter or even the black home owner (whose entrepreneurial opportunity is much more limited). However, where both are small-time junk dealers in the neighborhood, for example, the interaction will tend to increase as will the sense of having something in common. Therefore, the chief 
factor, as one would suspect, mitigating or making improbable an equalitarian and compassionate interaction situation, particularly between blacks and whites, is inequality in areas other than ethnicity.

When one group is a threat to the other, in any sense, interaction will be less psychologically rewarding and will be limited. When the neighborhood's white population sees itself as upwardly mobile, its interaction with blacks will be restrained. But once conditions have changed and mobility is no longer the normative expectation of the white population, the presence of black people is no longer a threat to that mobility. Williams deals with this notion of threat and suggests three correlated propositions to it. (p. 221) With the reduction of threat, interaction becomes more rewarding and consequently will be repeated. If there are shared values and shared interests there will be a stabilization of interaction. Even comradeship or love can develop. Though personal upward mobility is blocked or limited, the mobility of one's children can serve as a continuation of one's own upward-bound perceptions. However, when one's children have left home and are headed upward, the vigilant threat of one's black neighbors, particularly if they are long-time neighbors, can become less relevant to one's life than the degree of similarity among those left behind. This is the case in our study area.

Lack of shared values and customs among black people 
and Italian-Americans is dealt with in terms of boundary maintenance in Gerald D. Suttle's The Social Order of the Slum. 6 Suttle points out that black people, especially the young, engage in what he terms "hip" behavior. Further, he notes that the slum behavior of ethnic minorities, such as Italian-Americans, is provincial or village-like in character. (p. 137) Blacks in integrated neighborhoods who desire contacts with a large number of black people must travel outside their neighborhoods.

\section{ETHNIC ELITE--THE JEWS}

For the more completely "ghettoed" residents of the neighborhood, the maintenance of traditional customs becomes an important area of retreat from failure in the larger world. Stephen Birmingham in our Crowd outlines the path of success adopted by earlier Jewish Americans. These people, a majority of whom were German or West European Jews whose religion was reform rather than orthodox, quickly took to the pattern of American entrepreneurial success of the 1850's to 1900 's. They came to this country not because of reli- gious persecution or to escape the draft, as did Russian Jews of the next century, but because for them America was a place of opportunity. They did not come from grinding poverty as did their Eastern counterpart. They were a Western people imbued with the Protestant work ethic and the ways of a modern industrial state. Families on the East Coast included 
the Seligmans, Schiffs, and Lehmans. In the West, there were the Meiers, Weisses, Franks, and Loebs.

Birmingham deals extensively with the fight between Hill and Harriman over control of railroading in the Northwest. Indeed, the Schiffs and Loebs played a major role in acquiring for Harriman the Oregon Short Line and the Oregon Railroad and Navigation Company. (p. 238)

By 1905, the Jewish immigrant had changed. Russian - Jews had fled the pogroms of the East and settled in New York. Many moved West. Our Crowd notes that the Russian Jews were poor, tough, orthodox of religion and far more leftist in thought than their German coreligionists. (p. 344)

\section{A TYPOLOGY OF RESIDENTS}

In considering a typology of slum residents, the author chose to use an article by John P. Seeley entitled "The Slum: Its Nature, Use and Users". 8 Seeley establishes four major types of slum dwellers. (p. 10ff.) One: Permanent Necessitarians, among whom he includes the indolent or apathetic; the adjusted poor whose poverty has existed so long it has become a habit; and social outcasts, criminals, winos and drug users. Two: Temporary Necessitarians who are usually the respectable poor. These may be poor people, but they either leave the slum or plan to leave at some time if they do not become trapped in the neighborhood when their houses 
rapidly decline in value. Three: Permanent Opportunists, among whom are the fugitives who for either legal, credit or business reasons decide to live in the slum. The unfindables, who are quite similar to the fugitives, include people who refuse to pay taxes or debts and answer questionnaires. Four: Temporary Opportunists. This last group, like the permanent opportunists, is similar to the necessitarian type but specifically includes."greenhorns"and small scale entre- preneurs who, for example, buy a four-apartment building, live in one room and rent the other three.

Among the respectable poor, the most common group is the "trapped". These are the people who most frequently show bitterness at the turn of events in the neighborhood and who are the least likely to participate in new community interaction. As is the case with the white ethnic minorities in our study area, most frequently their friends have either died or moved out of the area.

\section{GEMEINSCHAFT-GESELLSCHAFT}

Chief among the theoretical notions involved in dis- * cerning the quality and degree of "community" in the Lair Hill area is Tŏnnies' Gemeinschaft-Gesellschaft model. 9 Tonnies outlines two basically polar and ideal types of community.

Gemeinschaft-Gesellschaft corresponds closely to Robert Redfield's ${ }^{10}$ folk-urban continuum. Gemeinschaft is a 
gathering of people both geographically and through time who feel they are of the same group. Most importantly, for our purposes, they feel in some way different from other groups. Intense emotional ties and a personal sense of identification are key characteristics in such a society. Kinship units and small preindustrial villages of feudal times are models for Gemeinschaft.

Gesellschaft is the opposite type. Gesellschaft societies define membership in terms of what are usually called rational criteria. Rational is used in this context to describe efforts to maximize production in terms of efficiency-rational from the point of view of those who assume the worth of industrialization, bureaucracy, and so on. In Gesellschaft communities, volunteerism in association in all major areas of social interaction is bound to the notion of self rather than group interest.

Gemeinschaft-like values are those older and/or antiindustrial mass production sentiments which include an esteem for craftsmanship, the desirability of intimate social interaction, and the ideal of the small village. These values are seen in the young people of our study in their rejection of career in preference for a life-style of gardening, home crafts, part-time factory work, and living on welfare. In this community, Gemeinschaft-like values are also a part of the elderly people's world. They are not financially successful. Gardening, intimate, extended family interaction 
and close community contacts are very much a part of their cherished activities.

\section{COMMUNITY AS TERRITORY}

Herbert Gans'l defines "community" as an "aggregate of people who occupy a common and bounded territory within which they establish and participate in common institutions." He contends that these institutions are important only because their location puts them within reach of their users and that otherwise they have little significance in relationship to the area. But, he adds, "it is this set of institutions and organizations which are used by the neighborhood to perform functions that cannot be taken care of within the peer group society." (p. 104-5) In Lair Hill, the Neighborhood House and events like sunday music concerts in the park are examples of such community institutions.

\section{THE GENERATION OF COMMUNITY CONSCIOUSNESS}

Gans also notes that the community members did not make emotional statements about the value or the uniqueness of their neighborhood. He-states that this changed when urban renewal threatened the area.

Indeed, only when the outside world discovered the West End and made plans to tear it down did its inhabitants begin to talk about the West End as a neighborhood, although, of course, they never used this term. And yet some felt sure until the end that while the West End as a whole was coming down, their street would not be taken, which helps to explain the lack of 
protest about clearance until it was too late. only after it was too late did people begin to realize that they did have some feelings about the entire area. Even then, however, they talked mostly about losing their apartment and being torn from the people with whom they had been close so long. 12

The "community" of our study has been generated by just such a change.

In Gans's examination of community creation and continuation, a distinct minority group located in a limited geographic area with more than one class operates as a virtual village in relation to the city as a whole. While in no sense a single ethnic minority, the people of Lair Hill exhibit a similar village-like reaction to the rest of the city.

Dealing with this concept of village-like behavior, Marc Fried and Peggy Gleicher,13 in "Some Sources of Residential Satisfaction in Urban Slums," found in their study of Boston's West End that there appears to be, in a given special area which is locally viewed as the limits of the community', a "widely experienced subjective boundary surrounding the local area and some of its immediate extensions which is virtually impermeable." The study proceeds to note that such an area provides a vast interlocking set of social networks and that the special area becomes, by definition, an extension of the notion of home. Suttles also recognizes this phenomenon.

Scott Greer14 (in Urban Renewal and American Cities) and Tom Landye $e^{15}$ (in his 1960 paper) argue that urban renewal 
programs generally reward the strong elements of the community, such as local government, business interests concerned with redevelopment and the local economy, and punish the weak local residents and small-time businessmen. Greer states that, in reality, there is no real community consensus in the development of an urban renewal plan.16 Local community representation, as it exists, is in the hands of the politically powerful. This is because market must be secured for the land once it is cleared and political support from city government must come in order for such a plan to get anywhere.

Greer and Gans both conclude that decisions which influence the process of urban renewal are generally made before local neighborhood consultation takes place. In the case of Gans's West End study, local politicians oppose such situations but are powerless to correct them. In Portland this is even more the case. For here, there is no governing body, based on neighborhood representation. Instead, there are city councilmen who, as mentioned previously, are elected at large, and have as much power as the mayor who is also elected at large.

Jane Jacobs in The Death and Life of Great American Cities $^{17}$ contends :

Unsluming hinges, paradoxically, on the retention of a very considerable part of a sium population within a slum. It hinges on whether a considerable number of the residents and businessmen of a slum find it both desirable and practical to make 
and carry out their own plans right there or whether they must virtually all move elsewhere. (p. 139)

In short, rapid turnover of population is the chief factor in the creation of a district marked by squalor or substandard housing. Neighborhood residents who see their housing as transitional and absentee-landlords are corollaries of the Jacob's theory of slum creation. Lair Hill, a potential slum, has young and old residents who do not desire to move. The voluntary Gemeinschaft of this community is a unique factor in its survival. This desire to remain persists despite the lack of normal, day-to-day conveniences--markets, cleaners, drugstores--in the area.

Redfield emphasizes the importance of the community members' perception of groups who do not live amongst them as outsiders, in spite of a shared culture and language.18 A sense of hostility towards outsiders on the part of the little community members is identified. The Redfield Indian models are small, closely knit interrelated groups who rarely communicate with outsiders. For these groups, there are those people or groups they know (friends) and those they don't know (enemies). In a more complex society, as Redfield shows, where communication with outsiders occurs frequently, a complicated set of concentric circles of interaction exist. In his example, divisions are made between village and district, section, tribe, the people of the study, and so on to the white government at the furthest circle. In addition, 
while contact exists with each division, distance is maintained or increased respectively as contact occurs with divisions further from the village and closer to the white government. While an obvious notion, it is an important idea. To a limited degree, a similar phenomenon exists in Lair Hill when inhabitants relate to the city and its people. For example, the author asked Lair Hill residents about a recent city proposal for urban renewal in their neighborhood. The residents tended to respond with a sense of great distance ("who knows what they're planning down there, those big shots") and powerlessness in regard to the actions of city government.

All of the above serve to suggest that a major force in the creation of this Gemeinschaft-like situation is less the product of true cultural affinity based on some similar values than it is the product of a locally perceived danger from the generally recognized disapproval and destructive intention of people outside of the neighborhood.

IX FURTHERING THE GENERATION OF GEMEINSCHAFT: SOCIAL INTERACTION

George Homans, in The Human Group, 19 outlines the process in which association among people in the Gesellschaft situation of the bank wiring room at Western Electric produces, eventually, a mutual attraction through the mere fact of interaction. (p. 243) This observation suggests a modern 
process in which friendships in informal group membership may develop from proximity. Coupled with the notion of a perceived exterior oppression, the development of friendships in Lair Hill is comprehensible.

While dealing largely with young people, Gerald Suttles suggests some ideas about coalition and interaction among different ethnic minorities living in a mutually shared neighborhood. 20 In his study, young Mexican-Americans and blacks separate themselves from each other by defining and occupying their own turfs. Similar spatial separateness can be seen in where and with whom individuals sit during musical activities in Lair Hill Park.

Suttles deals with the occasion of antagonists forming coalitions when exterior elements threaten the comfort and security of status quo, in this case the community structure. Social boundaries and tensions that exist among neighborhood groups are frequently resolved when still more distant groups threaten, as Simmel also suggested. By the summer of 1968 , while harassment by outside groups increased in Lair Hill, there was a definite tendency toward integration in the park."

X CONFLICT AND CONTRADICTION: COMMUNITY THROUGH ACCOMMODATION

The perspective of most of the immediately preceding is structual-functionalist in nature and particularly in the suggested analysis of the prime cause for the existence of a 
unifled community of attraction at Lair Hill. Yet, the author advances the preceding to be exterior pressure and, as such, it suggests an exterior conflict notion of community creation. Iair Hill is an extant community and, as such, it has function and, of course, structure. This does not negate the fact that its function for many of its members is one of resolution of conflict and that the kind of conflict that its members face lies in class and power relations (traditional areas of concern in conflict theory) in the greater society. If the majority of residents either dislike the police or the city power structure or other enforcement agencies--the building code office and the Portland Development Commission--then certain important Neo-Marxist ideas may be of significant use. Marcuse, in One Dimensional Man, 21 speaks of Max Weber's logical extension of the inevitable bureaucratization process into a paralyzing system in which contradiction is fostered: a system where technique or technical expertise is highly rewarded and at the same time thwarted; a society in which without any conscious manipulation or even with conscious manipulation, a totalitarian ethos may be maintained while the structures of democracy apparently" flourish. Essentially, all that is needed is that most means of production and communication be in the hands of a few. Then too, the all-important practice of 
repressive tolerance must be upheld.

For Marcuse, repressive tolerance is what others would call flexibility of the system, or even, the ability of the system to change. By this term Marcuse means that at the same time the city is repressive--it prepares, executes and admits to plans for breaking up hippie communities--it is democratic--it establishes and champions supposedly social equality projects like Model Cities. Repressive tolerance, then, is a device where contradictions can be allowed to flourish without resolution and where the system can, in fact, point to these contradictions as proof of democracy. of course, discredited groups, particularly officially discredited groups, can be repressed with general public acceptance simply because tolerance has been previously exhibited. Marcuse is included here because the notion of contradictions in a social context, such as those assigned to Lair Hill, will be used for explaining the community situation. The model that will be used is derived from Mao Tse-Tung's work on contradictions. While not dealing directly with problems of community organization or power, his distinctions between antagonistic contradictions--contradictions that stem from class conflict in society and can only be solved through revolution--and non-antagonistic contradictions--contradictions which occur in ethnic or cultural contexts, such as the difference between peasants and workers-help to clarify those qualities which separate groups of 
people along more than class lines.

Communities like Lair Hill face two major contradictions in their nature. Such places are very old and many who live there are old. And they are new and many who live there are both young and new to the community. Furthermore, they are mixed racially, black and white, in a society where blacks and whites do not live together notably well. This heterogeneity, according to Homans, moves toward homogeneity as a pure consequence of interaction by developing common values and sentiments. The appearance of young, long-haired Jews and Christians in the nelghborhood schule and chapel, and the existence of black people who have established friendships with some of the older white residents are examples of conflict resolution. In the Maoist-Marxist model 22 contradiction resolution is derived from a non-antagonistic relationship. In all probability, Mao does not mean that antagonism is expressed anger. Rather from his point of view, antagonism is an extension of class warfare. In Mao's Works ${ }^{23}$ it is stated that contradictions among the people are not antagonistic in terms of real interest, but that contradictions between the people and the ruling class are antagonistic and, therefore, important.

A distinction is needed between the notion of antagonism, or antagonistic contradiction, and the notion of conflict. Alvin w. Gouldner, in The Coming Crisis of Western Sociology, 24 points out that much of modern sociology, 
from Comte on, is derived as a reaction both to violent revolution, or any sudden major social change, and against backlash to that social change which will restore power to the old upper-class of Comte's time. Sociology has a positivist bias. It sees social change as occurring in the course of an orderly upward progression of humankind. Inevitably, for these positivist notions to be valid in terms of the West's modern republican form of government, they must accept the fundamental tenet of pluralism. In. modern terms, this means simply that there are many interest groups possessing different degrees of power who can, under - specified conditions, effectively exert influence upon policy. It is in this context, that simmel's notion of conflict must be examined and contrasted with the Marxist model of Mao.

Louis A. Coser, in his introduction to Georg Simmel, 25 describes dialectical tensions between the individual and society, harmony and conflict, and so on. This ambivalence, as opposed to commitment, according to Coser, is to be seen by simmel in even the most conflict-ridden of relationships." Simmel is a functionalist. Not a functionalist in the sense of Parsons or Merton who emphasize a pattern which makes for order, but purely in the sense of the notion of derivation. Simmel sees one situation directly as the function of a previous situation. In other words, where conflict has existed there will be derived a synthesis not a revolution. This is 
a Hegelian, rather than a Marxist, view of conflict. Simmel sees conflict as a necessarily reciprocal, rather than unilateral, phenomenon. Thus, for example, the rejection of others or outsiders serves to strengthen self or inside group. (p. $10 f f$.

Conflict theory is relevant in understanding the success of urban renewal. Simmel argued that domination does not simply depend upon imposition of the superordinate, but a reciprocal acquiescence by the subordinate, and interaction. This conception, while weak in that it ignores the real meaning of power (which is the belief of the subordinate in the capacity of the superordinate to crush the subordinate), does help to describe the kind of acquiescence that urban renewal undertakings, like Portland's South Auditorium Urban Renewal Project, make possible.

In Suzanne Keller's The Urban Neighborhood the notion of antagonistic contradiction as presented above is largely ignored. Keller concentrates instead upon what could be done to increase neighborhood use. The economic aspect is pushed aside for a moral set of suggestions on how city planners might proceed without the use of the broad-blade bulldozer. According to Keller, the neighbor role in each neighborhood, as well as neighborhood territory, varies from place to place. The social order of the neighborhood should be carefully ascertained by city planners before plans are executed. For example, if there is a variety of status 
groups in the neighborhood--Jews who have obtained a greater degree of economic success than blacks--a plan which is designed to serve only poor blacks is incompetent and more harmful than good. The effect of exterior pressures upon the solidarity of a neighborhood is largely ignored. While recognizing broad distinctions among neighbors along class and ethnic lines, Keller seems to pass over the sets of forces that make neighboring a significant response to city life as well as a part of it.

In Mao-Marxist terms, resolution of conflict where class interest is involved cannot follow simmel's or . Keller's model. It cannot be in the interest of large landholders or investment capitalists to give, for example, the property in our study area to the people of this area. In Maoist terms, land and people are "things" that are exploited by the capitalist classes. To give land, in a land reform move the scope of an urban renewal project, would probably be seen by these upper-classes as a dangerous precedent and a threat to their power. But an urban renewal project that turns the land over to these upper classes for exploitation, or no urban renewal at all, does not create the kind of contradiction suggested above. Since it is in the interest of the Lair Hill people to control the fate of the land on which they live, and since it is also in the interest of those who now own that land or can benefit by that land in terms of capital growth 
to control the real estate, a contradiction, which is in its very nature antagonistic, exists between those with capital to exploit and those not possessing the capital.

In this chapter, a number of concepts which relate to the Lair Hill community have been discussed. Factors which make for heterogeneity and inter-neighborhood conflicts were dealt with. Concepts which make for homogeneity were discussed. The generation of this sense of community was outlined. Central to these examinations was the hypothesis: that a Gemeinschaft-like situation has developed in Lair Hill because of outside forces which aré perceived by area residents as endangering the maintenance of neighborhood life-style, housing, and location. As we shall see, even the area's latest residents, the new young people, have developed an interest in the idea of belonging to a community, etc. They have made a conscious effort to reconstruct a "neighborhood" life-style which coincides with the traditional values of the older Lair Hill residents. Then too, the young people's "hipness" has been incorporated into the neighborhood life-style by the black people in the area.

Finally, distinctions between contradictions that have their base in unresolvable conflict and those which are resolvable, short of major change or revolution, are identified and used to explain and amplify the resolution of conflict and the perception of helplessness of Lair Hill's people. 


\section{CHAPTER IV}

\section{NEIGHBORHOOD HISTORY}

-One of the Commission's major objectives has been to blend citizen participation with the roles of local, state and federal agencies in the planning and development of its seven major projects."

--from "A Glance at the Work of the Portland Development Commission"

\section{Geographic Sources - 1900-1955}

Old city insurance maps are the principal sources of historical geographic information on the Lair Hill area prior to 1955. Please examine the maps in Appendix I. These three maps detail Lair Hill as part of Old South Portland at three stages in its development, two stages falling within the period of our immediate concern.

- The first (base) map shows the area near the turn of the century. At this time, the majority of streets were of mud and dirt. Wooden bridges spanned gullies at First, Second, Front, Water, and corbett streets. The high Southern Pacific Railway trestle on Fourth Avenue adjoined a series of stilted walkways and supports for a number of shops and homes which hung over the Marquam Gulch. One corner barbershop collapsed into the gulch in 1925.

The second map details the area just prior to urban 
renewal in 1955. Extensive land fills have eliminated the gullies on such streets as Arthur and Meade. Duniway Park has been developed. Ross Island Bridge has been built. Regular city blocks and occasional dirt streets extend to the heart of downtown Portland.

The third map indicates the area at present. Freeways run north, south, and east of Lair Hill. North of Arthur Street, neighboring buildings and a few access routes to the

- city center have been lost to the urban renewal project. As well, the 1968 housing code campaign has claimed several houses in the Lair Hill area.

\section{INFORMANT INFORMATION}

Informants' earliest accounts report that black people have lived in the Lair Hill area for most of its history. In the years immediately following world War $I$, there were three black families living in Lair Hill. One of these families, according to property records, has been in continual residence since 1915. Their home is located on one of the least desirable lots in the area. It first had adjoined the " Southern Pacific Railway trestle which later became the graded highway of Barbur Boulevard. The property was allegedly purchased by trickery. According to neighbors and friends, the black purchaser feigned greater poverty than was the case, brought the price down and then 
impossibly difficult terms.

Taped subjects who were members of the Jewish community in those early years recall attending school with children from these black families. They state, however, that more successful Jewish families in the community were already leaving the area, moving either toward corbett Street or to nicer housing uptown.

The population that began to fill the neighborhood from 1905 to 1927 was largely made up of "greenhorns"-recent immigrants from Europe. These were Italians and Jews and a few Poles, Ukranians and other Eastern Europeans. "Yeah, Poles, Litvaks and Russians." Subjects state that these "new" Jews were from Eastern Europe while the older neighborhood Jews were from Germany or even fourth to second generation American stock.

\section{RELIGIOUS LIFE}

From 1900 to 1958 , there were, at least, seven churches and synagogues in the old South Portland area. There were two Catholic churches--St. Lawrence at Sherman and First and St. Michaels (built in 1895) which is still standing at Fourth and Mill. The relative smallness of the Italian population, in relation to the Jewish dwellers, may be indicated by the ratio of two Catholic churches to five synagogues. The five synagogues in the area were orthodox. The majority were founded from 1909 to 1920. According to 
Interview, Eastern European Jews were orthodox in religious orientation. This fact is important when considering the situation of Portland's Jewish community at the beginning (in 1905) of this large influx of Russian Jews. By 1920, Lair Hill and old South Portland were home for this Eastern European population.

\section{THE EASTERN JEWISH INFLUX}

"The History of the Neighborhood House", by Louis Ga110, 26 House director, gives notice to the fact that the Lair Hill population was frequently undernourished and ill. This area was not only a ghetto in the sense of ethnic isolation, it was impoverished as well. Before the Depression and for many years thereafter, Neighborhood House offered free clothing and medical care to these people. Classes were offered in everything from cooking to the heavily attended English classes.

The response of the German Jewish community, a population whose religious orientation was reform and whose assimilation was complete by the 1900's, to the Russian Jews' con- dition was charitable and commanding. It was the German or Reform Jews who centered their social life around Temple Beth Israel, then at 13th and Hall. Temple Beth Israel had an organization called, in the appropriately assimilated manner, The Altar Guild. It, together with Beth Israel's Council of Jewish Women (created in 1896), formed in 1902 the 
Neighborhood Guild of the Council of Jewish Women which in that same year ran the first Well Baby Clinic in the city.27

Neighborhood House, founded by German Jews of Temple Beth Israel, appears to have served as a separated or segregated center which kept poor Jews and other poor of the neighborhood at a social, if not physical, distance from the well-established German Jews. In 1923, Beth Israel mysteriously burnt to the ground. A new temple was built in 1928 . Its location, N.W. 19th and Flanders, suggests both the increased prosperity and tendency to seek greater distance by the German Jewish community. At this time, the Northwest area was one of the finest in the city. 28

The cultural separation between German Jews and their orthodox brothers seems to be a contributing factor in the development of both resentment and a sense of uniqueness which is still visible in the orthodox community of Lair Hill.

No source could clearly set a date, but sometime during the above mentioned period, the so called Turkish or Sephardic Jews became an important element in the community. There has been a Sephardic temple in Portland ever since those early years. The most recently built of these temples is located on Barbur Boulevard at approximately the point where Grover Street would bisect Barbur (if Barbur were not on a graded roadway some 40 feet above Grover). It should be noted that few cities in the country have sephardic 
populations which have maintained their cultural integrity to the degree of establishing separate synagogues.

The Resser Israel synagogue on Meade Street is the only remaining "schule" in Portland. With the death of Rabbi Fain in the early 1960's, it became a prayer house with no formal congregation or services. Still, it is the most orthodox of temples in the city. It is a low-status synagogue in comparison to Portland's successful rich and hugely modern temples, but there is a minion in regular attendance at least three times a week, five or six times a week during the high holy days. One Wednesday morning in 1968 during the summer of the "hippie invasion", the old men of Meade Street were short a man in the minion. A member with a notorious drinking problem had stumbled upon one of the long-haired young people on second street and had discovered that the youth was a Jew... This was the beginning of the occasional attendance of sabbath services by longhaired males at Meade street. The congregation generally ends services with a formal sharing of good luck in the breaking of marble cake and bourbon thrown back by the shot. Three or four shots to a Mozel Tov.

\section{PHYSICAL ISOLATION OF THE NEIGHBORHOOD}

By the 1920's, a variety of commercial services were at the Lair Hill resident's doorstep. According to taped sources, there were two fish stores, seven markets, two drug 
stores, three bakeries, a dry goods store, kosher meat and poultry shops and other establishments within a five-block radius of the Lair Hill neighborhood. The trolley, which served what is now the Terwilliger school area, ran down First, then turned on Gibbs to Corbett.

The physical isolation that came to this neighborhood began in 1949 with the alteration of Front Avenue from a regular two-way street with many side stores to a semi-freeway with only one pedestrian overpass and one underpass for access to the Corbett area. Urban renewal and the freeways were the second of several changes that gave the neighborhood clearly defined physical boundaries. The 1968 Lair Hill Park incident--the gathering of many outside hippies and drug users in the park which drew police attention and community concern--was a third factor in the isolation of the neighborhood from other areas.

of those who remained after urban renewal and the like, there, are few who do not express a deep and abiding distrust of the City and its motives in matters which relate to themselves and the neighborhood. The findings from in-depth interviews were these: of 12 interviewees who spoke of urban renewal and city planning, 11 expressed suspicion of and bitterness ("they played us a dirty deal") toward city agencies. Asked why they thought the area was urban renewed, eight said for the city's financial benefit, two said for the sake of progress, and two had no answer. 
In spite of isolation, with continuity supplied by black and white multi-generational use of the neighborhood, a revived, though small religious life and additional cultural interaction provided by the park, a sense of place and uniqueness lingers in Lair Hill. Young people's frequently asserted interest in "neighborhood" as a notion and as part of a life-style (based usually on little experience until their entrance into the area) gives further support to the idea of Lair Hill as a special community, a unique place. Though many subjects note the loss of markets and other commercial shops once close at hand, they point out, as well, the new life in the community--young people's businesses including a natural foods store, psychedelic supermarket, candle and crafts gallery and leather goods shop.

\section{HISTORICAL HETEROGENEITY}

Before dealing with positive factors of "community," it seems necessary to talk about those factors which could keep the neighborhood members apart. To begin with, Lair Hill has a very heterogeneous population. Its earliest settlers were poor people. The more successful of these people, according to reports, tended to leave the community. Interviewees state that the smaller Italian and Eastern Jewish populations in the area became friends. And there were black families in the neighborhood. A photo in the possession of one of the black families shows the 
interviewee as a baby in his mother's arms on the steps of the Neighborhood House in the company of many other mothers and children who were identified by him as Jewish and a few Italian people.

Occasionally, when Jewish and Italian subjects were interviewed, some displayed either vague or no memories of black children in the neighborhood. Prodding revealed that they did know of the early existence of black families in Lair Hill but considered them unimportant or even of negative significance.

Tapes indicate a distinct difference between the Jewish and Italian residents and the new young white people and black people. In the case of the former two groups, Jews and Italians seem to function most often as landlords. They frequently hold one or more houses or apartments in the neighborhood as income or investment property. Two interviews indicate that such property was given as dowery. Most property seems to have been acquired by inheritance or purchased when successful people moved out of the neighborhood. Further, property was purchased during the panic selling and moving brought on by urban renewal plans in 1958.

While Jews and Italians are often the landlords of blacks and new young people, there is no similar economic relationship between blacks and new young white people. The only economic relationship between the two groups appears to be shared work efforts, such as scrap metal collection. 
older black residents tend to be seen by the new young white people as not possessing power over them or economic superiority to them.

\section{GENERATIONAI FACTORS}

There are very few Italian or Jewish children of earlier residents still in the neighborhood. Lair Hill's Jews and Italians are from 50 to 80 years of age. Black residents have family ties which span as many as five generations in Lair Hill. There are black teenagers, children and young adults as well as older black people.

Young white people span only two generations. The older white young people are in their teens through twenties. Roughly a quarter of these people have young children. Black and white children play together and go to school together. There is some interracial dating or at least sexual contact between blacks and whites and there are three married interracial couples, all of whom have chilaren.

It is important to note that the Jews and Italians in the neighborhood are relatively more financially prosperous than their black or white young neighbors. They regard themselves as culturally superior. They hold strongly with traditional values and have ties with Portland's larger Jewish or Italian community. But with two exceptions, all of the Jews and Italians interviewed expressed a high regard 
for neighborliness and other positive sentiments that they hold for this community.

\section{URBAN RENEWAI}

It must be remembered that the Lair Hill area was not always isolated. In fact, until 1960, it was the tail end of the old South Portland neighborhood. The community's feeling of threat from outside, from the city as a whole,

- was heightened in the years from 1954 to 1961. In 1961, acquisition of property was underway for the South Auditorium Urban Renewal project. It was during this period that Lair Hill became a being unto itself.

What remained then was negligible. Beautifully terraced front yards and houses had been eliminated with the widening of Front Avenue in the late $40^{\prime} \mathrm{s}$. The remaining residents along Front made do without the customary space for gardens and playing children. Five businesses, including $a, d r u g$ store, along the strip or nearby closed. The trolley was rerouted from First Avenue onto Front to Corbett. In 1954 , Front was fenced so that access to the corbett area was physically limited. ${ }^{29}$ By 1965, there were only two signal crossings and two paved sidewalks to the city center. There was no major market that could be reached without a long walk.

Neighborhood House, whose initial function had been the Americanization of greenhorns and whose later function 
was to provide a social center for Lair Hill and South Portland inhabitants, found more and more of its membership by the 60's in residents who would bring their children to the House to learn to swim and otherwise use the facilities. A Portland City Club estimate shows that by 1968 only 10 percent of the Neighborhood House members lived in the area. 30

Terry Schrunk, the mayor of Portland today, is the man - who ran for the city office in 1956. In the face of an unemployment rate unequalled since the Depression, interview subjects indicated that he promised as a major campaign item to create urban renewal projects to bring jobs to Portland. Newspaper stories at the time make no mention of this allegation.

According to Earl Kirkland, secretary of the Building and Construction Trades Council of the AFL-CrO, during those years from 1953 to 1959, construction was down 40 percent. This was the Eisenhower "planned recession" and its solution for Portland, where private financing was scarce, rested upon federally supported programs. This, of course, suggests that where similar economic conditions might prevail (as today, construction is down 50 percent) Portland politicians might again seek the solution to construction's plight through urban renewal; and Lair Hill has been contemplated for such a project. 31

It is important also to note that in the Citizens 
Advisory Council's public opinion poll on the question of creating and financing the Portland Development Commission (a necessary first step to urban renewal--passed in May, 1958) not even 50 percent of those interviewed had any clear conception of what the commission's task would be or the scope of urban renewal. The Advisory Council, it may be supposed, was created as an agency to support urban renewal. Following the poll, this council--sporting only one member - housed near the area to be renewed--spent much money on a full-scale "education program" to gain voter approval. The election literature on urban renewal gave no concise information on what was planned for South Portland if the measure passed. The measure passed and in late 1959 urban renewal was underway. 32

Residents in the South Auditorium Project Area fought urban renewal from 1958 to 1960. Private and class suits, initiative and referendum efforts, all were attempted. And failed. Old South Portland houses, the majority of which were over 50 years old and in poor condition, were leveled. 33

So strong was sentiment during this period of urban renewal that bizarre events often took place surrounding the actual project. The congregation of a Sephardic temple attempted to have their brick building moved rather than build a new structure. The temple collapsed. 34 (Local press thought the event rather funny.) According to taped 
accounts, the building was highly over-insured during the move. Continuity gave way to profit.

Shop owners hung large signs in their windows accusing the government of destroying the right of private property, of Nazism and Communism. One shopkeeper vowed through his sign that he would not move.

By 1963, the South Auditorium Urban Renewal Project was a virtual accomplishment. An old community of Jews, Italians, blacks, and a small number of gypsies was gone. In its place, deserted lots, high rise apartments and corporate office buildings gave flesh to the promise of the future.

There is statistical evidence, gathered by Tom Landye, 35 which tends to support the conclusion that the urban renewal project in no way benefited the area's former inhabitants, Several of this author's tapes deal with the notion that real profits in land speculation were made in South Portland. Seven subjects cite the case of a woman who fought the cash settlement given for her property as inadequate. She found herself with a court settlement which, not including legal fees, was $\$ 500$ less than the original offer. Subjects use this example to explain how resistance to governmental authority is hopelessly ineffective.

Tom Landye reported that of the 30 percent of those who had moved from the urban renewal area, for whom records had been kept, there was a rent increase averaging some $\$ 6$ 
across the board. For the total who moved $(470$ families were in the urban renewal area), relocation meant that 44.8 percent would be relocated in manufacturing zones, 16 percent in commercial areas, 34 percent in apartment areas and only 5 percent in residential zones. Sixty-three percent would be relocated in deteriorated or blighted areas. Fifty householders would be relocated on the right-of-ways for new freeways and would be forced to move a second time within a 10 year period. 36

The neighborhood has been subjected to numerous attacks upon its size and shape. Victims of each attack still live in the area. From World War II on, there is no 10 year span free from such an attack. In a neighborhood composed of people whose housing desires include the traditional home and yard, high rise apartments are not a viable alternative to their existing quarters, however dilapidated these quarters may be. For in Lair Hill it is still fairly quiet. Rents, are low, few units occupy more than two families and there are small back yards where people grow gardens. Artists practice their crafts. Until the drug frenzy of '68, police largely ignored crime in this neighborhood and it was a safe place for prostitution, drunkenness and soft drug use.

Emery Ingham, who operates the Psychedelic Supermarket at 2735 S. W. First, states that in 1958 city officials promised there would be no further south city urban renewal 
beyond Arthur until 1968. In 1968 the city of Portland was studied by the City for HUD to ascertain where poor, dilapidated or deficient housing existed. The study was to start with the area immediately south of the urban renewal project. By 1970, all of the housing on Barbur Boulevard near the corner of Hooker Street with one house excepted, had disappeared. The housing on Hooker adjacent to Lair Hill Park had been torn down. Two grocery stores and six additional housing units had been eliminated. All told, 20 separate households had been removed from the neighborhood.

City Council meetings, obstensibly concerning a proposed 11 p.m. park curfew, dealt extensively with the growing problem of drug abuse in Portland's parks. Much of the discussion centered around Lair Hill Park, the only park readily available to residents of the Lair Hill area. 37 Interestingly enough, the only area citizen complaining at those city Council meetings about park activity was the operator of a business in the area for a few years. The citizen claimed that industry would not be interested in the area until the young people were cleared out. It was in the months immediately following these hearings that the area was inspected for housing code violations. An official of the City of Portland announced in a hearing on urban problems in Eugene the following winter that Portland had attempted to solve its hippie problem through housing code enforcement in the Lair Hill-Corbett area. 


\section{CHAPTER V}

THE NEIGHBORHOOD

"Transformation of this once-blighted and economically isolated neighborhood on the downtown periphery into an attractive and productive area..."

--from "A Glance at the Work of the Portland Development Commission"

This chapter is a description of life in the Lair Hill area. It chronicles the interaction of the neighborhood's yarious elements. In addition, segments from taped interviews and descriptions of encounters by the author with members of the community are presented in an effort to capture a sense of the style, language and customs of Lair Hill residents.

\section{FROM THE INTERVIEWS}

A young white housewife:

You get so you know your neighbors enough so that when you walk up the street they say 'hello, how are the children?" My husband has been here a long time and so these people would sit and watch him paint the building and start working on it so they know him and they know what he!s done. They watched me move in and watched us having babies and growing up. I was walking up here to the corner the other day with the kids and one old lady hobbled out on the porch and stopped to talk about the kids and 'my, haven't they been growing up fast.' It occurred to me that she had seen me when I was first pregnant and then with that little one, and then pregnant 
with the second one and now with the little one being over a year. And that's really very nice.

\section{An elderly homeowner:}

I've worked very hard to pay for this and put up with the inconvenience of them putting the highway and all that grading in outside. And even now I have this traffic on both sides of me. Oh, it gets dusty. I have a good life here though. I have my children and it's home to me. But I always have that hanging over my head, that I'll have to make a change.

There was a piece in the sunday paper and it talked about a big survey going through here and it's going to cost a fabulous amount of money. How in the world did it ever cost so much money? It looks like graft or overpaid people. Why, when there's so many poor people, must so much be spent? They could spend that helping straighten up the neighborhood and have a lot of money left. They surely could. Just what that survey cost, just think what that improvement would mean to the people in this neighborhood. You bet you. There's a lot of people being paid in this town that have no more sense than a bunch of jack rabbits as to what is of necessity.

Two neighborhood black women:

How old are you, do you mind?

Uh, I'm sixty-seven.

Really?

Sure.

.How old are you?

Sixty-three.

In this neighborhood, all the ladies, even Mrs. uh, uh, ....she's what... seventy some, nobody seems as old, everyone's so alert and healthy... why is that?

I don't know. I guess we try to...

I think we mostly enjoy this neighborhood, people are so lovely and have, oh, not too much to worry about I don't guess...yeah, we take our troubles as they come.

\section{A neighborhood minister:}

Some of these people come out every sunday. And some I see in the neighborhood never come to church but we try to keep a good, friendly relationship. 
There are two or three families in the neighborhood who are Catholic who I know real well ... very friendly with us. And the lady up here on the corner has a little garden and everything. And they have been real great friends, she and the little Jewish lady up there, for years and years. They're always giving us things from their garden.

Now I don't know why but the people on the other side of Barbur Boulevard, no one on the other side has anything to do with this community. To my knowledge, I've never remembered anybody that lives on the other side of Barbur ever coming here and going to the church. They just seem like they feel that they're a part of a totally different group of people. They seem a little better, ah, everybody up there has jobs. They're working, some are in a little better financial shape and so on. So they definitely are separated in that regard. People down in this area, most of them are on a fairly low economic scale, a good share of them are out of work and so on. Totally different group of people.

\section{A Jewish woman of long residence:}

Well, I'll tell you the truth. I don't know that many people around here, because I don't bother with neighbors. However, the reason we don't bother with them is because people don't stay here any length of time. They're more or less like people on the go or transients... My friends were a lot of these people that were chased out of here by the first urban renewal. These houses were taken away and there was just a handful of houses from Arthur Street south and all the other houses north of Arthur, people were ousted out. And people that you have known and have been neighbors with for years, you know what type of people they are. But someone who moves in for two or three weeks and they can't afford to pay the rent for the whole month, naturally you can"t get to know neighbors like that.

A new young white couple:

When we first moved in there was a very heavy drug thing going on. Like there were a lot of people comin' to your door knocking and asking, you know, soliciting drugs...like it was out front, like pushing, and, uh, the cops did a heavy thing in the neighborhood... busted a whole bunch of people and they busted this little schoolbus that was right 
next to our house and, uh, now it doesn't happen. If people smoke, or whatever, they're doin' it discreetly. It's not something that's emphasized in the neighborhood. It's like a peaceful, mellow ...people keep pretty much to themselves. If they are out, they are very friendly with each other. Like a couple houses down there's some people livin' there that walk up the street and talk to us now, just walk by and stop and sit on the front porch and ...there are a lot of spades around...they're the people that usually come by. There's this guy named Heavy that hobbles around with crutches, really groovy, and he comes around and talks about the Lord to us, you know, talks about how the Lord is healing his legs. And there's this guy named Bill that is drunk all the time. He comes by and we give him somethin' to eat and take care of him a little bit. Then there's this guy named L.C. who's really neat..

\section{ETHNOCULTURAL GROUPINGS AND TYPOLOGY}

Essentially, the Lair Hill community now is made up of four major ethno-cultural groupings. These are: (1) the elderly Italian-Americans; (2) the elderly Jews; (3) multigenerational blacks; (4) "Bohemians", life-style artists, writers, students, etc. The older residents call the young groups the New Young People, and sometimes the Hippies. Ùsing Seeley's typology of slum dwellers, the majority of the first three categories are Necessitarians, either temporary or permanent. The latter group would probably be classified Temporary Opportunists.

The only type of Permanent Opportunists involved with Lair Hill are the landowners who, if they live in the neighborhood, would fit into the category of Necessitarians.

Seeley limits his observations to Chicago and 
Indianapolis in the 40's and 50's. However, his typology helps isolate the permanent residents from those passing through the neighborhood. Lair Hill has the Permanent Necessitarians, that is, those who display an intense apathy and an adjustment to that apathy. Many are social outcasts and many are adjusted to poverty. There are indolents, winos, drug users, fugitives and the like. But the smallness of the community leaves little space for a truly hot . fugitive. Unfindables and a few models or missionaries (Christians) also come to the neighborhood. The only greenhorns or beginners in the area today, as contrasted to 50 years ago, would be runaways who, of course, are also fugitives, and legitimate first-time home-leavers, such as students.

There are many Temporary Necessitarians in the neighborhood. They are those who, needing low rent and a tolerant environment, are necessarily there, but are "risers". These are, as mentioned previously, artists and students. of 12 people under 30 years of age living in the area, seven said they came to Lair Hill because rent was cheap, five said the "Bohemian" aspect of the community first appealed to them. Because seeley's scale is restricted to the slum and describes a place where people desire not to be, these newer arrivals who identify with the neighborhood do not closely fit any of Seeley's four categories. Less and less do we find among the students and artists in this community 
a desire to rise in income. This, in turn, suggests that while the value of living in the community may be initially economic, the community's values tend to be adopted by those who come to live there. The young people who do desire to leave this area (three of the 12 questioned) apparently do so only to get out of the city. They express little interest in living in a conventionally "better neighborhood". The area's new young people make distinctions among themselves on the basis of "hip" versus "unhip" and between those who regard themselves as part of the neighborhood and those who see themselves as opportunists using the community but not participating in it as permanent or serious members. Furthermore, this latter distinction is frequently a judgment imposed upon newer arrivals by longer term young white people. This imposed judgment is most often justified by the longer resident in terms of the new arrival's brief stay in the area and use of the neighborhood as an operational base for illegal activity.

Thus, we might categorize the new young people who are longer term residents as Necessitarians, and who are shorter term residents as Temporary Opportunists. Some students interviewed might also be placed in this latter category. For them, the neighborhood is only important for its low rents. It is a stopping place on the way to success for drug dealers as well. But still, some of these temporaries find their values changed through interaction with its more 
permanent residents.

There is evidence that interaction between these four or five groups is not always aggressively cooperative though a sentiment of community is apparent in almost every interview. Interviewees expressed the feeling that Lair Hill was a "good neighborhood". The new young people were frequently referred to as "nice", "friendly", and "not at all troublesome". On the young people's part, the consensus was that this was one of the "few neighborhoods left in the city." Yet, repeated as well was the comment by groups, particularly groups of longer residence, that people kept to thier own business. "The hippies stay on their own side of the street. They don't bother me. I don't care how many move in here."

Further, residents' almost conscious pact to mind their own business and to avoid calling outside agencies into the neighborhood to settle problems has meant uncustomary acceptance among residents of various street activities. While frowned on by some, being drunk or "tripping" on drugs in the streets is all right. Dope dealing and prostitution are deliberately ignored. Jane's famous house of prostitution, in existence for many years in the area, is mysteriously unknown to even Jane's next door (Italian) neighbor. Jane's is also unknown, while the tape recorder is on, everywhere else in the community. Unknown, that is, with one exception --a young WASP school teacher who has just moved into the 
area identifies Jane's house across the street as a brothel. Whatever people's true feelings for one another, roleassuming behavior generally calls for a friendly attitude. This is neighboring behavior as referred to earlier in speaking of Suzanne Keller's work. Saying "hello" in passing, asking after one's health, is expected behavior in the neighborhood. (This is not to say, of course, that not saying hello is so unusual, but rather that both parties in passing will, at least, indicate mutual greeting with eye contact and smiles.) Since the September newspaper article on possible urban renewal for Lair Hill, neighborly chat has switched from such pleasantries as "Nice day, isn't it?" and "Well, where have you been lately?" to "Did you read that article?" and "When's it gonna happen?"

III THE END OF ONE ETHNIC LINE, ANOTHER CONTINUES

Italian-Americans and orthodox Jews, whose social contacts are principally limited to their own social group within the community or even outside the area, say that they find in Lair Hill an "old time neighborhood." Lair Hill's worth for them is its identity with the past. It should be noted that this link between past and present is most frequently mentioned by these two groups whose presence in the neighborhood has no "future"-not having children of their own still living in the neighborhood.

Conversely, black people, whose social contacts are 
more varied in terms of age and ethnic group encounters within the community, have a multi-generational standing. Resident grandparents, grandchildren and their children provide a continuum not just of past memory and present action, but future hope as well. A sense of the past and the rich nostalgia that surrounds it is, for these people, not necessarily drawing to a close, as it is for the local Italian and Jews. The black people's children are still in the neighborhood.

The following pasticcio from the author's notebook is presented as a piece of Lair Hill. It attempts to capture a certain style, language, or life quality, that is characteristic of the neighborhood. The event is actual. The subjects, here, are older black men and women standing on a street corner one evening.

On a moonlight spring night against the green pickup, the wine goes round and the old man, fatly Black and crutch-lame, speaks with late night power, his insolent hope that you will believe him, sly old mother fucker that he is, and knowing a thing or two jack. The first black man? Recall when an' how it was? Lawrence here, Lawrence, am I not right Larry? And Larry agrees and the fat man tells it. Larry here had 700 dollars and the man that owned that house there, and that one as well, he give Larry a contract deal. You know, buy on the contract when you pay, that way, oh, maybe 75 dollars a month. only he figures this nigger ain't got no money in depression like it was then and can't get none either. Larry acts kinda poor and jews the price from 1,400 dollars right in half and that ol" sonofabitch still don't think Larry gonna be able to pay for it, but he had it right along and pay him the whole kit and kaboodle the next month too. So the man lose the land and Larry he live here ever since. Now you own that and two other, ain't that right? 
Larry agrees and around she goes and the ol' man fatly black give a sweaty look to both sides and face the fender all green and take out his monster, fat-looking dick and piss a mighty run against the fender and the black tire; all steamy yellow in the new mercury vapor lamps. The smoky part rises up to block the old concrete crud of past sidewalks, maybe 30 feet above where the cops with radar wait for the rush of latenight drunks. Funny noise right then and ol' Missis Jones, she calls from the corner house, tired from work and washing bedpans at county, for her son to come in and he pretend not to hear her, but the men look away and give him no help and sadiy he go up to her and we see him no more until later when he rapes once too often a white chick and she turns out to be high family and puts him away for several years until he is 21 .

\section{CONDITIONS}

The neighborhood itself is in various stages of deterioration. The most recent houses were constructed in the 1920 's, the oldest (fine examples of Victorian CarpenterGothic) before the turn of the century. There are two apartment houses and six multiple dwelling units. Several homes are communals; not necessarily planned communes, but shared rent situations. Properties in good repair are either owner-occupied or rented by landlords who live in the neighborhood. Neglected properties, such as an old house on Hooker Street with a cistern full of garbage and rooms junked with newspapers and other refuse, have drawn rodents and cockroaches to the area. There are the condemned buildings, which have either been poorly repaired or not repaired at all. In general Lair Hill appears to be a blighted, or, at least, run-down neiǵhborhood. 
In 1965, houses in the area rented for $\$ 45$ to $\$ 75$ a month. Today, bottom rent is $\$ 65$ and top is $\$ 125$ a month. Some houses kept in minimal repair have experienced no more than a $\$ 10$ rent boost over the past 10 years. Poorly kept and renovated houses and apartments serving the community's shorter term residents both have disproportionately higher rents. The area maintains a high level of occupancy. Efforts at restoration have been made and homes have fared well in several instances. New young people, who turn to long-term residency, repair plumbing, install wood stoves (fuel for which is gotten off the local condemned buildings) and fashion integrated sculptures and mosaics in their dilapidated quarters. They frequently violate building codes in the cause of art.

Older residents, as well, have sought improvements-adding exterior siding and tacking down new linoleum carpets. In the homes of many black people, repairs have even been made with scrap material. These latter homes are the area's poorest in furnishings and it is obv ious that the families have fewer resources for fixtures than the new young people or older white householders. Then too, as one black woman said for several residents, "I was going to paint the place real nice, you know, but I read that piece in the paper (about possible urban renewal for Lair Hill) and thought no use fixing up...though I sure don't want to move." 
Interviewees living on Front Avenue claim that a downturn in neighborhood conditions began with the construction of the Front-Harbor Drive extension in 1949. But most older residents set the date from 1958 on, when urban renewal took the northern portion of the area. It was at this time, as mentioned previously, that panic selling and moving took place. People remaining in the neighborhood seemed reluctant to invest in renovations until the expected next wave of urban renewal had indicated its boundaries.

This suggests that individual initiative (and corporate capital) hesitates before fixing up areas which have become isolated by urban renewal projects and which seem destined for renewal themselves. Thus, a kind of slow-down effect rather than "productive" environment is possibly generated by urban renewal. Investment capital does not flow into these isolated pockets the project creates and, therefore, possible community improvements are waylaid. Eventually, inspection programs reveal a blighted area in need of urban renewal.

\section{$v$ CONTINUITY AND TRADITION}

It is continuity, in terms of place and the traditional values of neighborhood life, from one generation to the next that seems of great importance to Lair Hill residents. This continuity is found in several areas of community life. The Meade Street Schule, Kesser (Crown of) Israel Synagogue 
and the Friendly Community Chapel on First avenue, owned by the Union Gospel Mission, still serve the neighborhood. Schule regulars are former or present South Portland residents. Reflecting the latest addition to the Lair Hill population, the Friendly Chapel hosts a congregation that is about 50 percent young people. Recently, the Prince of Peace Coffeehouse in the basement of the chapel opened as a social spot for these young people.

Neighborhood House, the area's long-standing formal social institution, has again started community-directed programs. There is a free childcare co-op, largely run by local young parents. There are occasional rock dances for the "Bohemians" and older black kids, which supplement the preteen to teenage dances. The Golden Age club holds weekly meetings and social events for people over 65 years of age. It should be noted that Neighborhood House served only the residents from the older communities until agency pressure from United Good Neighbors forced recognition of the area's changing composition and the development of recreation facilities for the new young people. Possibly, the opening of these facilities to the "hip" community marked the formal recognition by the old Guard, Jews, Italians and black people, of the new young people's permanence in the neighborhood. 


\section{STRAINS ON NEIGHBORING}

Within the community events occur which can strain any relationship. The following from the author's notebook is

one such event.

Out one early night, Donney and James decide once more to have some PUSSY. This gal comes along and they come behind her saying, "Hey, Ruth" and "you ain't Ruth," which is obvious and she smiles nice and they get each on one side of her and ask real nice, can they walk with her and say that they go to Portland State College. What a shuck, they only fourteen you know. She agrees sadly cause she wishes to be alone. And soon James put his arm around her and she object and Donney, he stick a knife in her back real smooth and gentle so it just barely cut her, and they tell her bout her pussy and how she hasta, and they pull her off the road and into the bushes of Duniway Park and she start this twenty-three year old college girl shit about this being a bad way to get love and they make her lie down and first Donney get it out and get it in and feel her good, and then he finishes and splits and James do it for a long time and tell her this is the eighth time and he plan it to be the last. As he button up, her eyes still full of his face and fearing his madness, she runs onto the track field and there is a man there, a U.S. Marine and he gives her his coat and takes her to the police who take her to the hospital where they prove it's true and then back downtown to look at mug shots of every badass nigger they got on file. And she even remembers Donney Jones's whole name and a week later they take her to Lincoln High and she looks through the window of the door and they are standing together and they see her and one, James, never looks at her, but the other, Donney, he stares back and she feels very sad and goes home and bathes and does not cry.

Donney's family believe him when he say there were three guys and he left before it really happened. They ask for help with the TV on and the wine flowing good, and ol' Larry is there and the ex-Independent Progressive Party Drunk Black who is an educated and wise ol' man. But it is no good, and Donney is guilty and the lies about the white giri's freely fuckin' ways cannot help and until he is twenty-one Donney will be in McLaren. 
On one level, this event contradicted the notion of a community avoiding exterior forces in dealing with its problems. It also widened what had been a relatively close relationship between the new young people and the black residents of Lair Hill. But it is exactly because the event forced these two negative results that it is most important. The young lady's reporting of the rape to city police was a virtually choiceless matter under the circumstances. . Her violation of the community ethic of settling differences without calling in outsiders rendered the attempts of the boy's family to label her a "whore" and "nymphomaniac" understandable. But there was little community sympathy for such talk. The girl was a well-known member of the longer term new young people's scene.

The boy's actions discredited him among many of the blacks in the area. The censure was all the stronger because of the ties which had been endangered by the event. "He shouldn't had done it," said an older black resident. "Why I knew her and she was no tramp. He caused his family to be shamed." One black woman claimed she stopped visiting Donney's mother shortly after the event.

The boy's family left the neighborhood a few months after their son's conviction. They moved to the east side of the Willamette River. Today, no one in the black community speaks of the rape. When questioned about the event, one black interviewee insisted that the tape recorder be 
stopped and that the preceding question be erased. He was not related to the boy's family.

On the part of the new young white community, though expressing distaste for the crime of rape, censoring of the boy's actions seemed to be based on the fact that the girl was not an outsider or new arrival, but a long term resident. Subjects who discussed the crime said they were glad that the boy's family had left the area because they felt, as one interviewee put it, "there was a lot of bitterness and some people were getting scared of any black dude in the neighborhood."

Thus community solidarity was maintained. Offenders found themselves discredited or snubbed. They left the neighborhood. Few residents now speak of the rape, and even fewer recall the tension caused by the event.

In much the same way as Donney's crime, the drug dealers in the area during the summer of 168 received the scorn and censure of the neighborhood. The drug dealers were privately accused of being "uncool" and opportunistic. They were said to be the cause of The Heat coming into the neighborhood.

\section{LIFE-STYLE AND WORK}

Residents of the Lair Hill community are largely working class, unskilled or semi-skilled laborers and menial attendants. There is a high level of unemployment--of 50 
eligible persons questioned, 17 were unemployed. Many are on welfare. Seventy percent of the older residents interviewed were retired. Their forms of income usually were: social security checks, welfare supplements, insurance policies, small investments and low-rental incomes.

Employment areas for black residents include scrap dealing, seasonal crop harvesting, and service occupations. Two black interviewees were disabled veterans. Three black men were observed by the author at various times to panhandle for money.

of the new young white people who were not on welfare or supported by savings accounts, selling of art objects and menial part-time jobs accounted for their relatively low incomes. In four households, musicians had casual gigs. There were two white scrap dealers. In two houses small illegal business dealings were noted.

Casual and occasional employment, student status, and arts and crafts work rather than a full-time 40 hour work week, meet the needs of most members of the community. From the author's notebook, "the way it is" on Second Avenue between Arthur and Hooker Streets.

By 166 there were a lot of young people around, rents being still as low as $\$ 45$ a month for a fiveroom apartment. of course, heat is from a wood stove. Gathering wood takes cooperation. In the fall, young white men and older black men get together and gather scrap wood and cut it up. on Second Avenue, a young white artist called Ralph and one of the old black men make a vegetable garden, gather wood and cut it together. Upstairs, where 
Ralph, his wife and baby live, it's wood heat and wood cooking. They're on welfare. The black people downstairs are farm workers in season, welfare recipients otherwise.

Blind John, an older orthodox Jew, seems to own most of the property around Second and Arthur. He gets around, his tenants say, far too often to each of his places. John's got no notion where he'll go if they urban renew again. Ralph's landlady, Mrs. F., an old Jewish resident, lives next door to Ralph. She won't spend a penny painting her place or theirs. Ralph's father-in-law, who is a successful businessman, offered to buy Ralph's place, but Mrs. F. wouldn't sell. She likes it, wants to keep it to remember, she says.

Mrs. F. knows Ralph. Mrs. F. knows Blind John. Ralph knows John. Ralph calls the Meade street Schule John attends the Jewish church. Ralph's friends won't live in John's places 'cause John comes around too often. John's rents are high too, it is said. John and Mrs. F. know Mr. V., another orthodox Jew, whose wife is the sister of Mrs. X. When the hippies were everywhere, Mr. $\mathrm{V}$, who is sick and can hardly talk, asked the guys at Merchants of Warm, the local hip self-help agency, to tell the kids (who were dopers, by the way, passing out and drooling on the steps of the schule) to stop spitting on the building. A couple of windows at the schule got broken. But the First Avenue church and the Schule both got new young regulars at services for the first time in years. The minister at the church came to Lair Hill Park regularly when they played music there. He knew soul food when he saw it. He tolerated the dopers, Gypsy Jokers, and freaks. But outsider evangelists were yelled at and hated. It was when they needed a minion at Meade street that the new young Jews got invited, long hair and all. One question only. Listen, you sure you're Jewish?

\section{FUN, MUSIC AND TROUBLE--INTEGRATING FORCES}

In a mild, wet climate, when it is not raining or especially cold, Lair Hill Park, two blocks of lawn and play facilities on the area's northwest border, becomes a center for community activity. Since the arrival of the new young 
people, there has been, with some regularity, acoustical or electrical music in the park. Musical activity and the gathering together of people did reach two significant, distinct peaks in which the total community took part.

The first of these was in the summer of ' 66 and ' 67 . At the time, what was primarily a "hip" young people's gathering, limited principally to young locals and their friends, began to include other persons in the neighborhood. .Young and older black people and white musicians from the area shared wine, food and marijuana in the park. It was in the summer of '66 that several older black men promised that the Black Elks would exert what power they had to obtain park permits for electrically amplified instruments.

Limits of exchange in the park could clearly be seen in the groups' physical locations and types of interactions. The white young people generally sat close to the performing musicians at the southeast end of the park. Young black people and young interracial couples, mostly teenagers from Lincoln High School, sat left of the former group, closest to Second Avenue. Behind the young of both races, the older black people sat at park tables with their picnic lunches. Further back, towards Barbur Boulevard, white people with children and the two or three local interracial couples with their children sat on the grass or picnic cloths. (See Film)

Jewish residents, while rarely in the park during 
musical events, said, when questioned, that they liked these gatherings, enjoyed the music. When city officials informally asked a number of old-time residents their opinion of the park gatherings only three solicited complaints could be found.

For a long time during the years directly following the arrival of the white young people, black and white winos who lived in the community would treat these new arrivals as outsiders, panhandling them four or five times a day. This action stopped, however, when local blacks and whites objected to the treatment over the park microphone. The last panhandling of this type was carried out by Mr. B., a local black resident, in the summer of '67. He persuaded an unwary white band leader that he was "passing a hat for the boys in the band." Mr. B. then insisted on pocketing half of the collected sum. Many persons gathered at the park got very angry and community pressure forced Mr. B. to scratch his plan..

From the author's notebook, this is taken from two accounts of an incident in 1966.

Bill, a new young man and white musician, lived at the house that Fred, a likewise musician, kept. At the time, Fred, a runaway, and Dee, another runaway, were living with Bill. Mouse, yet another runaway, was a frequent overnight guest. One spring day, when only Bill was home and while the black lady and the white lady across the street were sitting on the porch of the white lady's home, a policeman came to Bill's door. He asked Bill if Mouse was there. Bill told the policeman that Mouse was not there and that he refused to let the 
policeman inside the house. Before the policeman left, he said something like this to Bill: Listen you, Mouse's father has a gun and he knows where you live and he says he's gonna kill you if he finds his boy here. So you better save us all a lot of trouble by turning Mouse over to me now. Bill denied that Mouse was there and the officer left.

Five minutes later or less, Mouse's father appeared on the porch with a pistol. While he was in the process of threatening Bill's life, a police car with three officers inside stopped at Bill's place. The officers raced up the stairs to the front porch which is a full flight above the street. Bill asked them to take away the angry, shouting father. As he made his request, he stepped out on the porch, closing the door behind him but keeping the screen door between himself and the four men. One policeman, a sergeant, winked at Mouse's father and asked him if he wanted Bill taken downtown. Mouse's father said yes and stepped aside as the sergeant pulled the screen door out of Bill's hands and shoved him forward to the steps and against one of the patrolmen. This second patrolman then began to drag Bill down the front steps. Bill went limp, was hit several times on the head, then dragged by the feet down five wooden and seven or eight concrete steps. When the two ladies across the street saw this, the black lady called out "let that boy go" repeatedly. A white neighbor asked the police what they thought they were doing.

When Bill got back from jail, many hours later, the next door lady brought him some chicken. Their friendship continued. The black man who owned the house two doors down from Bill took to telling Bill of his own experiences with the police. And when, two years later, Bill left the neighborhood, the neighbors stayed friends with Fred and Mouse who still live in the house.

During this same period, juvenile officers who claimed they were looking for Dee, illegally entered a number of houses, among them a now condemned and destroyed home on Grover street. The police agents entered and after searching several rooms began looking in drawers and behind bookshelves for the runaway girl. When Ed, who lived then in Bill's house, heard that the police were there, he entered the home and demanded to see their warrant. When it was apparent that they had no warrant, he went upstairs, took down and loaded a 12-gauge shotgun and ordered the officers from the premises at gun-point. They did not return. And when the story got around, 
Mr. V. of the Meade Street Schule said Mazel Tov somewhat sadly.

From the author's notebook, as a Merchant of Warm.

Another night, a lonely walk across the park commences. On the children's merry-go-round there are maybe eight runaway teenagers. They're lying on their backs. One pushes the merry-go-round around with his leg. In the softest most gentle voices imaginable they are singing, "don't play with me 'cause you're playin' with fire," rendering the angry Rolling Stones' sweet and innocent.

"Hey," the walker speaks. One girl replies, says hello. At last the walker asks "Why is tonight so magic?" and thinks but does not say 'How is this night different from all others.' And she answers "righteous mescaline." The walker walks home across the park.

The second peak and first major problem concerning the park came in the summer of 1968. By then, people who did not live in the Lair Hill or Corbett area were flocking to the park first every sunday, then every day. Lair Hill Park was The Scene, a "little bit of old Haight-Ashbury." Psychedelic salesmen, hard narcotic dealers, speed merchants, runaway teenagers, motorcycle gangs like the Gypsy Jokers and the Cossacks, Portland state students, weekend hippies-in short, "outsiders" were making Lair Hill Park their Place To Go. The Portland Council of Churches Youth Ministry Program, under the direction of Gene Horn, focused its attention upon this new street population. In June of ' 68 , both the local and national press printed an estimation made by church leaders and the Youth Ministry that Portland and Lair Hill could expect an invasion of 50,000 hippies. Later months would see the city government and the church council 
locked in combat on the question of how to handle the "hippie invasion."

From the author's notebook, the '67 scene.

It starts on a February Sunday after the first big grass bust and all the news gets bad. In the rain they talk about making their inner discoveries visible. They plan to build a community here based on hope, art, and dope. But the press shows and so does a girl from San Fran with a grin and a plastic drum which turns out to be a big seller in the psychedelic shops. Yet, the sense of no work making all play a dull hallucination grows. But by warm spring, the $\mathrm{PH}$ Factor Electrified Jug Band, and before them, the Provos with free soup and the good folk musicians have come to play. One day for the first time, the old and junky sound truck comes giving them Factor power. The music commences and there is a joyful first in the sun and dancing and a very good feeling. But of course, The Heat arrive and give a ticket worth ten dollars at any police station for parking on the lawn. The flower bearers give them spring colored daffodils and even that early, they are afraid and fold-up their windows and back out across the grass with frozen grins; but it isn't that important and ten bucks is raised and the thing keeps growing. More and more heads, dopers, and nothing can stop it it seems like. But the word spreads and the local spades while sharing wine wanna score grass and teenies by the tens, then hundreds, are hip to it. The PSC faculty sunday picnic here and there are young, beautiful sixteen year olds and forty year olds and ten year olds and toddlers and drunken local shameful old niggers male and female twitching their bodies as memories warm deadened muscles to lively hope newly found. Permits are secured and bands promote themselves and it is all free and growing LOUDER ALL THE TIME.

From the author's notebook, the '68 scene.

The papers headline the building inspectors are gonna look into the dirty, foul, hippie housing and Emery recalls that in ' 58 when things got urban renewed, the city council had promised no more tearing down for at least ten years. And now it is the summer of 168 and all these dirty dirties hanging 'round and ol' HUD says we gotta inspect the 
whole city and why not start RIGHT HERE IN IAIR HILL (just a chance choice, of course). So they come creeping round and right away landladies and the city are rid of thirty people's housing, just like that and nobody can say shit.

"Old lady lived here fifteen years and even when next store was a house, you know with some fine meat, she be here and happy but now she hafta move," say the man and Larry is not happy but he don't do nothing and sure as shit don't say nothing too loud and at last the man put his hat on and stagger off.

Fat, twenty-three year old white lady with black 01 man on and off and five kids. She has to go too. Soon the streets get colder and the park is muddy with hundreds of unwashed feet. In the rain, in the mud, crowding the sidewalk they stand, grass, acid, speed, smack, softly crooning their old sweet song. When it rains too hard, they huddle under the one tree on the corner and sell each other the baddest, least genuine dope the world has ever seen.

Soon everyone is stopped and searched and the crime rate soars out of all the wildest policeman's hopes and desires. The wind touches the bare skin of last year's flower children and they wonder what kind of a scene there is in L.A. anyway, and the people who live here grow fewer and the feeling is gone forever and the old ladies who used to smile at you don't and the windows of the schule and the Psychecelic supermarket are broken and a kid one day stabs another $\mathrm{kid}$ and there is first blood. Here we go, at last, a problem, a.... This is a job for SUPERCOP.

\section{OUTSIDERS AND INSIDERS}

Area residents, both the new young people and the old people, resented the arrival of the street population. All subjects questioned saw the events of this time as an invasion by all manner of outsiders, from weekend hippies to police officers. It was a time when locals could not comfortably walk through the park or relax in the neighborhood. This is one account by a young white mother who lived near 
the park.

There's been a great community feeling, I think. And what we saw the summer of 168 with the park curfew and everything was just devastating as far as the community. After it was over, after the year had passed, people began to sort of gather around again and form their community again. But it was a devastating thing... The publicity that surrounded the whole park thing made it a very public neighborhood with tons of tourists streaming through and by the end of the summer made the scene at the park pretty ugly as far as hard drugs. Also, I saw a number of cases of kids, local kids, walking across the street in the middle of the block down here and being arrested for jaywalking which around here is absurd... Also, they sent down inspectors, building inspectors to close down houses and condemn them, many of which didn't need to be condemned. So I think at the end of that summer and for quite awhile you didn't see many young people around because I think that many of them had been frightened away and were not about to live down here and be harassed. It was a scary place to live for awhile.

Interviewees felt that law enforcement agencies, churchmen and city inspectors made matters worse because they failed to distinguish between the people, particularly the new young people, who lived in the neighborhood and those who were only passing through. A sense of community suggests itself in the realization by residents of the distinction between those who were there because they wanted to live there and those who were there because it was The scene or because there was economic gain to be made in the area. As mentioned earlier, neighborhood self-identification may occur more as a consequence of the kind of crisis that happened in 68 than is generally conceived.

Lewis Coser's book on simmel, in dealing with the 
consequences of conflict, emphasizes that out of conflict an altogether different situation frequently develops. As the above suggests, out of the inspections and the over-crowded conditions in the park with its apparent drug abuse evolved a clearer definition of who was a part of the community and who was not.

\section{$X$ SOCIAL CONTROL AND POWER EFFORTS}

During the crises of '68, "hip" residents attempted to control and deal with neighborhood problems. They formed an association called the Community Cooperative Organizing Project (CCOP). Many young and old residents attended the three CCOP meetings held at the community church. Several of the older residents at these meetings clearly distinguished between those who lived in the area and were young and had long hair and those who did not live in the community and were young and had long hair.

At one typical CCOP meeting, an elderly black man complained that a rock and roll band had moved in next door to him and that they were making noise all the time. A white woman suggested that the police should be requested to set up traffic signs so people would not speed where there were children in the area. A middle-aged man proposed that the police abandon cars for old two-man beat patrols around the neighborhood. Some of these suggestions were taken in petition form to City Hall, but were ignored. Young white 
residents did put out posters on keeping the park clean and did manage to move drug traffickers and crowds in general away from the Meade Street Schule and most residents' homes.

Formal lines of communication were opened through CCOP with the mayor's office and, with less success, the police department. For neighborhood members, city government is structurally distant, and members behave as though such government was essentially a distasteful force of nature moving, when it pays notice at all, against the community like a flood or earthquake. This is, as Redfield suggests, an essential phenomenon of concentric circles of distance occurring in a complex social order.

\section{FACING URBAN RENEWAL}

In November of 1970 , a new community organization took form with the apparent purpose of preventing urban renewal. Neighborhood House lent the group its facilities. For what is at stake is survival not just of a community but of its residents. "If you move my mom from here now, put her some place else, she'd last, I guess, six months. She's lived here all her life, can't get adjusted to another place," explains the son of an elderly Italian woman in residence. The son cites the example of a mother and daughter who moved for the South Auditorium Urban Renewal Project. They rented an apartment on the east side of the city. The mother was about 70 years old and within six months after 
the move she was dead. A Jewish resident claims, "They found them places (after the urban renewal clearance) but they were lost because this has always been their home. This has--I don't even know another area to live in."

Longer term new young people in the neighborhood, while only in one case owning their homes, have invested time and effort in them. Though not as threatened for personal survival as the permanent resident homeowner, they - face higher rents and less desirable locations in the city's shrinking pool of available housing.

For either group, young or old, public housing makes no provision for home gardening or flower cultivation. Electrical music is not permitted in high rise apartments. And land in the country, as well as suburban housing, is out of the economic reach of most Lair Hill residents.

The irritating presence of "outsiders," various agencies of the government which will be present if a study of the old neighborhood is made according to HUD regulations, could serve to intensify the antagonism.

It should be noted that conflicts among the people of Lair Hill become less important, as has been shown, when the greater conflicts, those that threaten the very existence of their homes, come to the fore. The intrusion of the outside teeny-boppers, the police and code enforcers who threatened both tenant and landlord in ' 68 , and now frequent talk of urban renewal, all serve this purpose. 
Once again in Simmel's terms, a wholly new situation is being born out of conflict. Simmel's view of this process as a creative one, and of Hegelian rather than Marxist proportion, offers up a hope which could drive those in Lair Hill to either block urban renewal altogether or limit such a program to renovation, repair and restoration of the existing homes. Even such a program might mean little unless ownership was made possible at fair prices to the people who live on the property. Of course, that is confiscation and redistribution--two very Marxist-Leninist notions. The residents feel that this is unlikely. In the face of this, older people interviewed expressed a desire to remain in Lair Hill coupled with a strong pessimism. The same feeling was expressed by the new young people. These groups share, as well, a desire for simplicity, a home and garden sentiment, the notion of minding one's own business in the sense of not bringing outside forces into the area to settle differences and fear of the future.

If there is to be a struggle in Lair Hill it has only just begun. And if it is to produce unity in simmel's or even modern Marxist terms, it will be because the people of Lair Hill have consciously decided that Lair Hill is a neighborhood and that its people are unified if only in that. 


\section{CHAPTER VI}

\section{CONCLUSION}

Lair Hill's neighborhood history has been examined with emphasis on two aspects: first, the arrival of the four major cultural groups to the area; second, the physical isolation of the area which produced the community pocket itself. Of the four cultural groups, three--Italians, Jews, and blacks--are long term residents. (The blacks, though early settlers, gained in numbers mainly during the years proceeding World War II.) The fourth group is the new young white people whose arrival en masse dates only from the mid $1960^{\prime} \mathrm{s}$.

The main task of this thesis has been to deal with the interactions of these groups in terms of two contradictory phenomena. One phenomenon is the homogeneity of the Lair Hill population's attitudes and values and its Gemeinschaft response to exterior forces which threaten the survival of the neighborhood. The heterogeneous properties of this integrated, but culturally differentiated set of four groups make up the second phenomenon.

Cultural similarities between the long term residents and the new young people were examined. Common anti-industrial values and strong sentiments for the past were 
discussed. The continual sense of oppression by exterior forces upon all of Lair Hill's people was studied in terms of the resident's shared sense of community.

The new young people's life-style of near poverty and apparent disavowal of the Protestant work ethic, while at odds with the work ethic of older Jewish residents, is ameliorated not only in a mutual nostalgia for the past, but by the shared religious stance of segments of the community.

- The appearance of new young people in synagogue and chapel is an example of this. At the same time, the "hip" way is acceptable to many people of Lair Hill, both black and white, for whom upward mobility has been to a greater or lesser degree blocked. In this sense, the influx of new young people, where cooperation and interaction has ensued, has helped to lessen the bitterness of those who are "trapped" in the neighborhood.

The case of Jewish landowners who have experienced, if not in their own lives at least in their children, the phenomenon of upward economic mobility was contrasted with the situation of the relatively economically immobile black residents. This economic distance is one factor for heterogeneity in the neighborhood that goes beyond simple cultural differences.

Attacks upon Lair Hill by exterior forces include the following: (1) the widening of Front Avenue into a main arterial highway; (2) the South Auditorium Urban Renewal 
Project; (3) the creation of a freeway network that further separated Lair Hill from the core city; (4) an intense housing code inspection and demolition campaign that came as an apparent response to the "hip" scene which had developed in the neighborhood. The housing code campaign begun in Lair Hill in 1968 was followed in 1970 by the Portland Development Commission's interest in a proposed $\$ 478,000$ "study" of Lair hill for apparent urban renewal purposes. Both in 1968 and in 1970, neighborhood associations were formed to fight exterior threats. The latter association is presently active. It has gained support from all elements of the community; property owners and renters, old and young, black and white. In that, there may be hope for the survival of the Lair Hill community. Yet despite their involvement in organizational efforts, many subjects of this study recall the failure of suits and protest during previous urban renewal and express a sense of helplessness and distance from those in power. Still, the "hip" population, now recognized as holding permanent neighborhood membership, is a new, relatively hopeful force with which to be reckoned. A sense of community has grown in the face of what appears to be a threat to Portland's isolated neighborhood, what outsiders have called Portland's "hip" pocket. Though Lair Hill may be the ideal type of pocket community, it is not the only one in Portland. In other parts of the city there are similar geographically isolated areas 
with a sense of identity as a community despite a diverse population whose interests are not necessarily cojoined. Goose Hollow in Southwest Portland is one such example. After the Fremont Bridge extensions are completed, at least two other examples in which "hips" and blacks comingle will exist. In the Northeast there is evidence that the area from Broadway to Interstate Avenue and Interstate Five Freeway is another such pocket community.

It is a hypothesis of this paper that Lair Hill's future is a natural experiment testing the Maoist-Marxist theory. If this integrated neighborhood can direct its own improvements, if it can gain funds for that improvement, if the land is not turned over to big capital or government agencies for massive redevelopment, then a turning point in the powerlessness of the American small community shall have been reached. Certainly the next few years will be the test. 


\section{FOOTNOTES}

Luniversity of Chicago Press, Chicago \& London, 1955.

2Barney G. Glaser and Anselm L. Strauss, Aldine Publishing Co., Chicago, 1967.

3Random House, New York, 1968.

4Many programs now in progress to revive neighborhoods and improve services within those areas are formalizations through institutions of these generally informal structures. Model Cities Program in Portland encourages the creation of a formal neighborhood political structure, through which small scale urban renewal is conducted. It also has organized neighborhood clean-ups, arranged for empty lots to be used as garden space, and hopes to set up adequate emergency child care services and so forth for the neighborhood. No attempt is being made to simplify the existing formal channels of such action. The consequence of this may be the creation of an artificial and exteriorly imposed political structure within the neighborhood, a structure which actually affects the lives of neighbors in a way that decreases the sense of neighborhood in a given area.

1964.

5prentice-Hall, Inc., Englewood Cliffs, New Jersey,

6University of Chicago Press, Chicago, 1968.

7Dell Publishing Co., Inc., 1967.

8From the Journal of the American Institute of Planners, XXV, No. 1, (February, 1959) pp. 7-14.

9Ferdinand Tonnies, Gemeinschaft und Geselischaft (1887), tr. and ed. by C.P. Loomis as Fundamental Concepts of Sociology, American Book Co., New York, 1940.

10Robert Redfield, The Little Community, University of Chicago Press, Chicago, 1960 .

lilThe Urban Villagers, The Free Press, New York, 1962.

12 Ibia., p.105. 
13 From the Journal of the American Institute of Planners, XXVII, No. 4, (November 1961).

14 Indianapolis, Bobbs-Merrill, Co., 1965.

${ }^{15}$ The Background of Urban Renewal in Portland, Oregon, Thesis presented to the Division of History and Social Sciences, Reed College, Portland, Oregon, June 1960.

${ }^{16}$ Urban Renewal and American Cities, p. 120.

17 Random House, New York, 1961.

18 The Little Community, p. 113.

${ }^{19}$ Harcourt, Brace and Company, Inc., New York, 1950.

20 The Social order of the slum, p. 128.

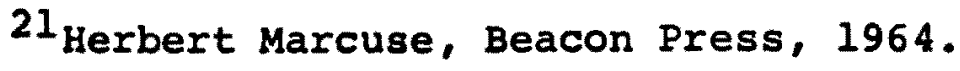

${ }^{22}$ Mao-Tse-Tung, "The Correct Handling of Contradictions Among the People," in Quotations from Chairman MaoTse-Tung, Foreign Language Press, Peking, 1966, p. 45 .

${ }^{23}$ Selected Works of Mao-Tse-Tung, Vol. I, Peking, Foreign Language Press, I957, p.344.

24 Alvin W. Gouldner, Basic Books, 1970. pp. 105-108.

${ }^{25}$ Coser, ed., Prentice-Hall, Inc., 1965, p. $10 f f$.

${ }^{26}$ Louis Gallo, mimeographed unpublished manuscript.

27 Ibid.

$28 \mathrm{Julius} \mathrm{J}$. Nodel, The Ties Between, A Century of Judaism on America's Last Frontier, Temple Beth Israel, Portland, 1959, p.47 f f.

${ }^{29}$ During the years when Lair became separated from the rest of the city, several other areas were cut off as well. The development of the Ross Island Bridge access ramps and the extension of Harbor Drive through Front street into Barbur Boulevard, as previously mentioned, isolated Failing School and a six or seven block area surrounding it from the Corbett area, Lair Hill, and the downtown core area. Access to this block of land was limited to an overpass at Hooker street.

The completion of Interstate Five, of course, virtually terminated river access by foot for the area's residents. 
The Harbor Drive extension and urban renewal project also isolated a block of housing running from Arthur to clay, north and south, and from Harbor to Macadam, east and west. This area was divided yet a second time in more recent years by entrance ramps for the freeway as it moves onto the Marquam Bridge. This area was once part of successful older Italian and Jewish housing.

30 From informal proceedings, the Portland City Club Subcommittee investigating urban renewal in the Portland area, Portland, Oregon, November 1970.

31 "Portland State University Housing," booklet by the Portland City Planning Commission, June 1970.

32 Tom Landye, The Background of Urban Renewal in Portland, oregon.

33 Ibid. , p. 65.

34 The Oregon Journal, October 23, 1965, "Sephardim Replacing Crumbled Synagogue," page unknown, exact date of destruction unknown.

- ${ }^{35}$ The Background of Urban Renewal in Portland, Oregon.

36 Ibid. , p. 65

37 In 1965, Duniway Park was filled and "given to Portland State University for athletic use. The park was no longer readily accessible to the rest of the city. The annual picnic reunions of many old South Portland Italians at the park were temporarily postponed, to be resumed this year at a park across town. 


\section{A LIST OF WORKS CONSULTED}

Anon., Insurance Maps of Portland, Oregon, Sandborn-Ferris Map Company, New York, publishers,

- 1901 corrected to 1908 , Vol. I. , 1909 corrected to 1926, Vol. II. , 1909 corrected to 1955, Vol. I.

Birmingham, Stephen, Our Crowd, Dell Publishing Co., Inc., 1967 .

Cartwright, Dorwin P., "Problems of Objective Observation" in Research Methods in the Behavioral Sciences,

Festinger, Leon, and Katz, Daniel, eds., Holt, Rinehart and Winston, New York, 1953.

Coser, Lewis, A., ed., Georg Simmel, Prentice-Hall, Inc., 1965 .

Duhl, Leonard J., M.D., ed., The Urban Condition, Basic Books, Inc., New York \& London, 1963.

Ewald, William R., Jr., ed., Environment for Man, Indiana University Press, Bloomington, 1967.

Fried, Marc and Gleicher, Peggy, "Some Sources of Residential Satisfaction in Urban slums," in the Journal of the American Institute of Planners, XXVII, No. 4, November 1961 .

Gallo, Louis N. , The History of the Neighborhood House, imimeographed, unpublished document.

Gans, Herbert J., The Urban Villagers, The Free Press, New York, Glasser, Barney G. and Strauss, Anselm L., The Discovery of Grounded Theory, Aldine Publishing Company, chicago, 1967.

Gouldner, Alvin W., The Coming Crisis in Western Sociology, Basic Books, New York, 1970.

Greer, Scott, Urban Renewal and American Cities, Bobbs, Merrili, Co., Indianapolis, 1965.

Homans, George, The Human Group, Harcourt, Brace and Company, Inc. , New York, 1950. 
Jacobs, Jane, The Death and Life of Great American Cities, Random House, New York, 1961.

Katz, Daniel "Field Studies" in Research Methods in the Behavioral Sciences, Festinger, Leon, and Katz, eds., Holt, Rinehart and Winston, New York, 1953.

Keller, Suzanne, The Urban Neighborhood, Random House, New York, 1968.

Landye, Thomas, The Background of Urban Renewal in Portland, Oregon, Thesis presented to the Division of History and Social Sciences, Reed College, June 1960.

Liebow, Elliot, Tally's Corner, Little, Brown and Company, Boston, 1967.

Mao-Tse-Tung, Selected Works, Vol. I, Foreign Language Press, peking, 1966 .

Marcuse, Herbert, One-Dimensional Man, Beacon Press, 1964.

Nodel, Julius J., The Ties Between, A Century of Judaism on America's Last Frontier, Temple Beth Israel, Portland, 1959.

Peak, Helen, "Problems of Objective Observation," in Research Methods in the Behavioral Sciences, Festinger, Leon and Katz, eds., Holt, Rinehart and Winston, New York, 1953.

Redfield, Robert, The Little Community, University of Chicago Press, Chicago, 1960.

Seeley, Hohn, "The Slum; Its Nature, Use and Users," in the Journal of the American Institute of Planners, $\mathrm{xxV}$, No. 1, February 1959, pp. 7-14.

Suttles, Gerald D.. The Social order of the Slum, University of Chicago Press, Chicago, 1968 .

Teller, Judd L., Strangers and Natives, Dell Publishing Co., Inc., New York, 1968.

Tönnies, Ferdinand, Gemeinschaft und Gesellschaft, (1887) tr. and ed. by C.P. Loomis as Fundamental Concepts of Sociology, American Book Co., New York, 1940.

Warner, w. Lloyd and Lunt, Paul S., The Social Life of a Modern Community, Vol. I of Yankee City series, yăle University Press, New Haven, 1941. 
Status System of a Modern Community, Vol. II of Yankee City Series, Yale University Press, New Haven, 1942 .

, and Srole, Leo, Social Systems of American Ethnic Groups, Vol. III of Yankee City series, Yale University Press, New Haven 1945.

Weiss, Thomas, On the Street Where You Live, Thesis presented to the Division of History and Social Sciences, Reed College, Portland, Oregon, May 1968.

Whyte, William Foote, Street Corner Society, University of Chicago Press, Chicago \& London, 1955.

Williams, Robin M., Jr., Strangers Next Door, Prentice-Hall, Inc., Englewood Cliffs, New Jersey, 1964. 


\section{APPENDIX}

$* *$ 


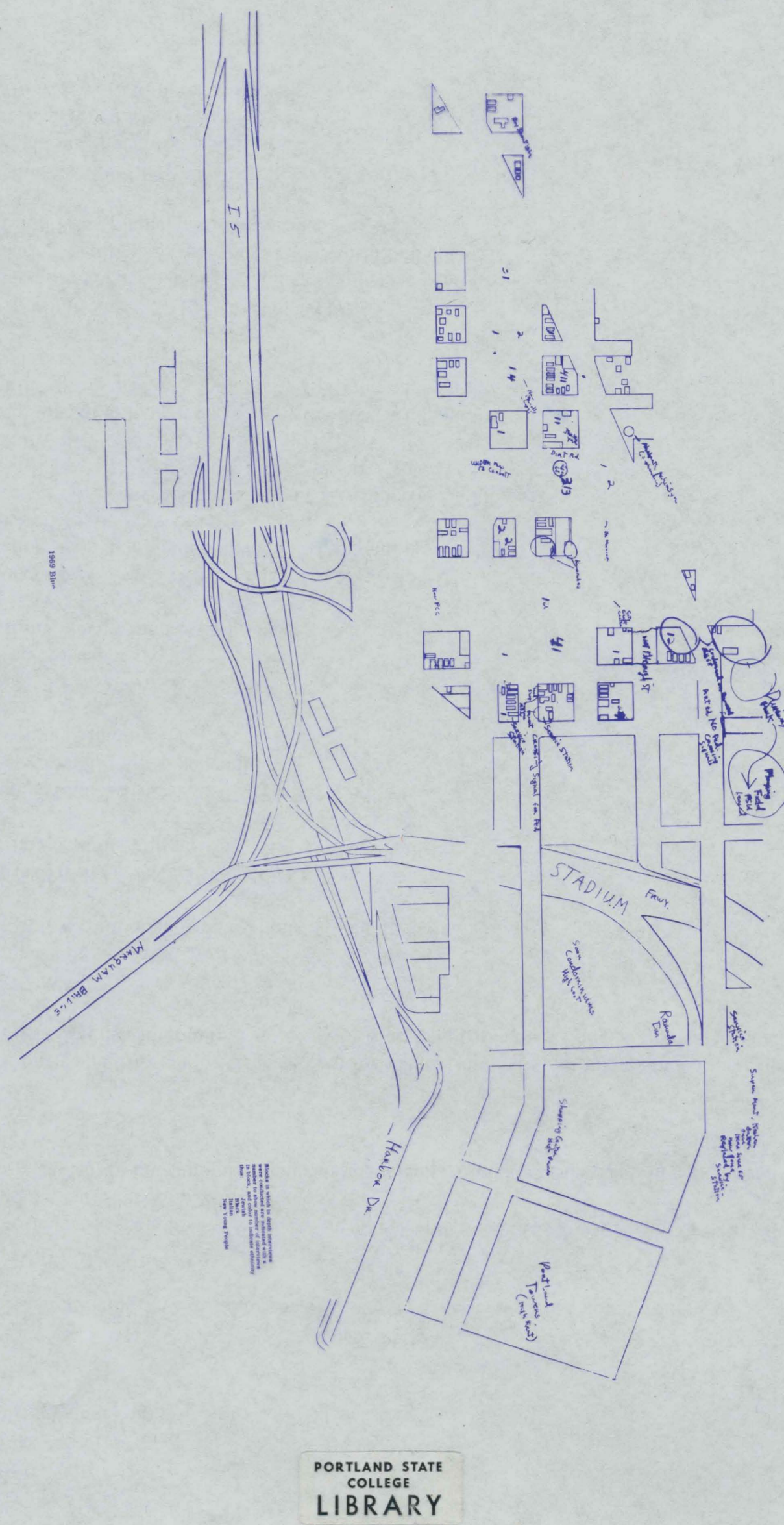


$\angle D 4349$

A 85

1971

.47

c. 3

pocket 2

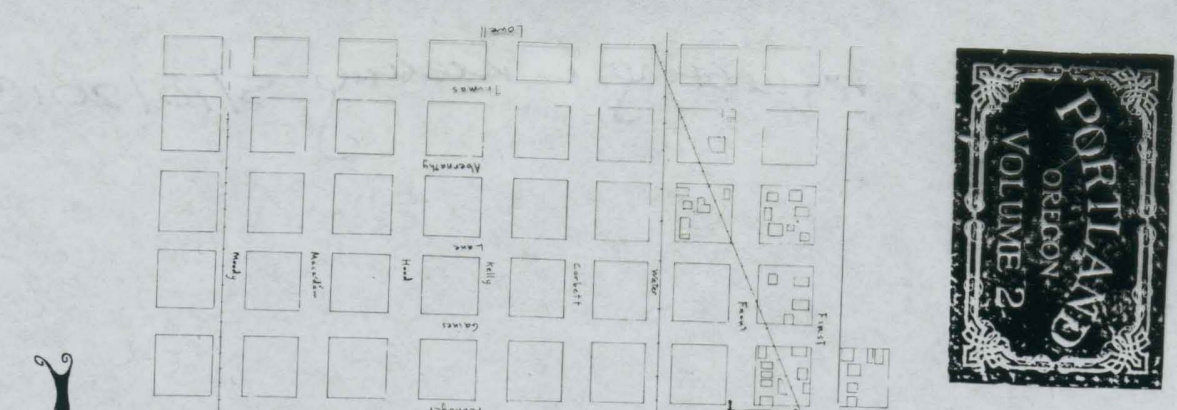




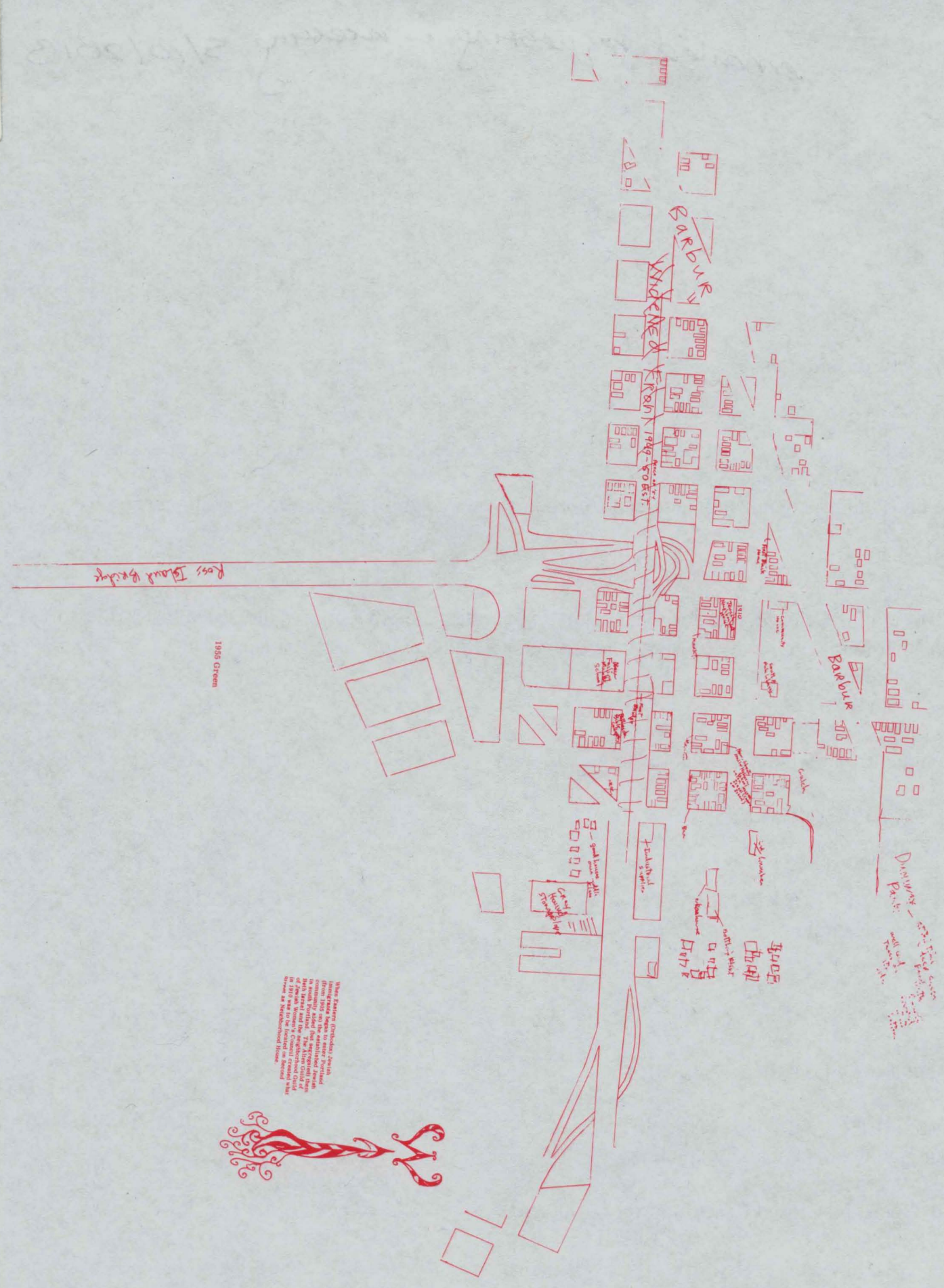

